10 years ESJ

Special edition

\title{
Ethics and Economics of Medical Supplies in the COVID-19 Pandemic
}

\author{
Hansong Li \\ Harvard University, Department of Government, USA \\ Yifei $\boldsymbol{W u}$ \\ Harvard Business School, USA
}

Doi: 10.19044/esj.2021.v17n31p87

Submitted: 27 May 2021

Accepted: 16 August 2021

Published: 15 September 2021
Copyright 2021 Author(s)

Under Creative Commons BY-NC-ND

4.0 OPEN ACCESS

Academic Editors: Georgios Farantos \& Nikitas-Spiros Koutsoukis

Cite As:

Hansong L. \& Yifei W. (2021). Ethics and Economics of Medical Supplies in the COVID-19 Pandemic. European Scientific Journal, ESJ, 17 (31), 87.

https://doi.org/10.19044/esj.2021.v17n31p87

\section{Abstract}

Background: The distribution of healthcare resources across local and global communities has triggered alarms throughout the COVID-19 pandemic. Injustice and inefficiency in the transfer of lifesaving medical supplies are magnified by the urgency of the public health crisis, ramified through pre-existing socioeconomic tensions, and further aggravated by frictions that plague international cooperation and global governance. Aim: This article explores the ethical and economic dimensions of medical supplies, from the microcosm of distributive algorithms to the macroscope of medical trade. Methods: It first analyses the performance, strategy, and social responsibility of ventilator-suppliers through a series of case studies. Then, the authors seek to redress the need-insensitivity of existing distributive models with a new price-based and need-conscious algorithm. Next, the paper empirically traces the exchange of medical supplies across borders, examines the effect of trade disputes on medical reliance and pandemic preparedness, and makes a game-theoretical case for sharing critical resources with foreign communities. Conclusion: The authors argue that the equitable allocation of medical supplies must consider the contexts and conditions of need; that political barriers to medical transfers undermine a government's capacity to contain the contagion by reducing channels of access to medical goods; and 
that self-interested public policies often turn out to be counterproductive geopolitical strategies. In the post-pandemic world, the prospect of medical justice demands a balanced ethical and economic approach that cuts across the borders of nation-states and the bounds of the private sector and the public sphere.

Keywords: Ethics, Economics, Medical Supplies, Public Health, Crisis Management, Trade War, COVID-19 Pandemic

\section{Part I. Introduction}

The outbreak of a global pandemic strains healthcare resources at all levels of the civil and global society, from households and hospitals to institutions of local, national, and international governance. But distributive justice in the global medical market poses one of the gravest challenges during the COVID-19 pandemic. The failure to deliver proper protective equipment, diagnostic devices, and therapeutic facilities to the neediest hands is a political, economic, and moral failure of the international society in global contexts.

The causes of this failure are multidimensional and polymorphic. To start, the scarcity of medical supplies results from shocking disruptions in the supply chain and dramatic fluctuations in customer demand, a reality to be reckoned with by not only economists but also ethicists. As the medical supply chain suffers workflow disruptions due to the very epidemic which makes its production so vital, the very lives of labourers are at stake, along with the products they are tasked to produce. Under both economic impetus and moral urgency to expand their plants, facilities and factories encounter unprecedented obstacles to their most basic operations. As more workers risk infections, yet more are summoned to the antiviral war, in a race against time. Firms of humbler sizes, in particular, struggle to ramp up production with a modicum of relief aid, due to their smaller and slower cash flows and limited capacity to muster alternative financing tools within a short span of time. Suppliers find themselves under as much obligation to fulfil the social cause as scrutiny to maintain the same if not higher standards of quality and regulation. Faced with such supplier-side challenges, the medical market scrambles to optimise supply chain management in order to offset the overwhelming pressure of the public health crisis. As the pandemic unfolds through an unpredictable timeline, the world has also witnessed striking shifts in customer demand, which ebbs to the extent of eliminating entire businesses, but skyrockets in a matter of hours in the healthcare industry. Such increases are not only in scale, but also in kinds, within the medical market. For instance, during the pandemic, U.S. demand for protective garments and respiratory devices outpaced the demand for non-emergency medical goods, but drained 
medical labour, space, and funding to the point of stalling non-epidemic medical care.

Both supply-chain disruptions and demand-side fluctuations cast a shadow on the protocols for the distribution of scarce resources. On the frontlines of the anti-COVID campaign, the lack of proper devices directly jeopardises the social responsibility of care-providers as moral agents (Ćurković et al, 2020). Thus, the economic question of distributive efficiency is inseparable from the bioethical problem of social justice (Rhodes et al, 2012). Here, even ethicists critical of economistic notions of efficiency in normal times defer to and rely on a functional medical market as an instrument to end the pandemic, since improved efficiency in medical exchange (e.g., optimising prices and logistics) is not only desirable, but necessary. Already in earlier pandemics, notably the influenza, scholars called for mixing moral sentiments with economic analysis in the global governance of pandemics (Thompson et al, 2015). In the case of the 2006 outbreak of avian influenza A (H5N1), market incentives, regulation, intellectual property, and liability each played a crucial role in ending the pandemic (Gostin, 2006). Scholars have likewise underscored the importance of the prices and patents of antiretroviral drugs (ARVs) in Africa's fight against AIDS (Reich and Berry, 2005). In general, during a public health crisis, well-regulated market-based mechanisms such as promoting competition, signalling incentives, and nudging behaviours acquire an ethical force. Therefore, the presumption that 'economic concerns' necessarily trump ethical ones is an unproductive partial truth (Ćurković et al, 2020). Although unimaginative critics of neoliberalism identify the generation of capital in the healthcare industry as a symptom without a plan to cure the disease (Ahlbach et al, 2021), their very failure proves a powerful catalyst for change. No doubt, the enormity of the epidemic invites extraordinary initiatives and interventions beyond normal market processes. Too often, seemingly generalisable market-based solutions which require entire ecosystems to succeed stumble at the myriad obstacles along the fault lines of socioeconomic disparities (Rodríguez and Urbanos-Garrido, 2016). To design workable solutions to new crises rooted in intractable problems, contextual intelligence must be added to sound strategies and scientific management (Khanna et al, 2010; Khanna, 2014).

This paper takes a capability-based approach to supply-chain optimisation and crisis management. In Part II, the authors study global ventilator-providers and resource-allocating platforms through financial analysis, case studies, and interviews. The paper identifies a set of key capabilities for firms to accomplish supply-chain restoration and disruptionrecovery: information design, portability, and the ability to contract and disperse with greater flexibility. Critical capabilities for customers, on the other hand, include their capacity to communicate need in a mixed regime of 
conventional and emergency distributive mechanisms, to secure the right to transparency in pricing and bidding, as well as to hold public offices accountable for taking both need and inequity into the formula as the authorities distribute scarce resources across socioeconomically disparate communities. Therefore, it falls on both suppliers and customers to bring critical care to vulnerable populations disproportionately affected by the pandemic. After all, by closing down the public sphere, the pandemic threatens the very ecology of relational ethics (Gardiner and Fulfer, 2021). So far, scholars have called for better access to care and information, medical goods and services, non-discrimination, and reasonable accommodation for the disabled (Sabatello et al, 2020). Others call our attention to the 'gerocidal' and generational effect of the pandemic (Cohen, 2020), as existing triage systems raise questions over the old body as a legitimate object of proper health care. In fact, COVID-19 is not only 'gerocidal' but also 'gynocidal,' in the light of new medical evidence on the unique plights of women during the pandemic (Wenham et al, 2020; Burky, 2020; Cousins, 2020). The needs of such vulnerable demographics have prompted scholars to rethink triage-based allocations - first come first-served, egalitarian, or priority-based-which save lives under constraints but fail to redress broader societal inequities. However, it should be pointed out that the triage protocols cannot even address the purpose of "saving the most lives possible" (Tolchin et al, 2021). For even with national universal health care established and the recruitment of marginalised groups into the medical task force accomplished, the shortage of medical resources during a pandemic remains an ethical plight. Therefore, it is imperative to improve the allocative algorithm of medical distribution through globally integrated supply chains.

With this task in mind, Part III proceeds to ask: are various auction models the proper way to allocate resources to global buyers at the height of the pandemic? Are some justified in bidding away resources from others? Should customers reasonably expect suppliers and intermediaries to adhere to a stable pricing guideline, in spite of the gross imbalance of supply and demand in the medical market? Even granted a level of transparency on a bidding platform, is it ethical and efficient for customers to encounter a pricebased and need-indifferent algorithm that matches buyers and sellers? Or are they right to expect a higher level of demonstrated need to win them more favourable terms of access to the resources they would otherwise lose in a bidding game? What, after all, counts as the 'best offer' in such a scenario? And what 'just system' yields a 'fair deal'? By revising the distributive algorithm, this paper proposes a price-based but need-conscious allocative method.

Given the scarcity and stagnation of medical supplies at a global scale, the ethics and economics of international trade is of vital importance. 
Scholarship has shown that trade-policy responses to the pandemic, whether export controls or import liberalisations, leave a long-term impact on the world's politico-economic structures (Evenett et al, 2021). To restrict export and facilitating import, The U.S. Congressional Research Service also adds the measure of prioritising domestic production (Hart, 2020). In Part IV, the paper considers the political economy of the COVID-19 in two steps. First, the authors study how global trade disputes leading up to the COVID-19 outbreak affected US medical imports, hence its preparedness to contain the contagion. On a parallel front, a game-theoretical simulation yields equilibria strategies for hypothetical governments to balance domestic inoculation and vaccine export. Indeed, the paper argues that the antiviral campaign is a global project. Public policies designed to lock down resources for the domestic audience, ranging from manipulating medical imports to banning vaccine export, run the risk of deepening the pandemic in the space between states. On the contrary, the international community recuperates faster and better by collaborating to foster a benign ecosystem for the global medical market.

\section{Part II. Medical Suppliers in the Pandemic Crisis}

A sketch of the crisis facing the global medical supply chain in the introduction naturally leads to the question: how do medical suppliers perform in these uncertain times? What are the strategies to overcome obstacles in pursuit of opportunities? Part II first reviews the supply-chain disruptions and demand-side fluctuations of the medical market, then analyses representative global firms that manufacture medical devices, along with distributive platforms that match overstretching suppliers with hard-pressed customers. The authors seek to understand the challenges faced by medical suppliers through case studies, analysis of financial reports, and interviews with managers. The paper discusses both crisis-time innovation and long-term strategies. The chapter ends with a case for how firms could and should create social impact in pandemic relief.

\subsection{Review of Supply-chain Disruptions and Demand-side Fluctuations}

The COVID-19 pandemic has affected the global supply chain of the medical market in several significant ways. It disrupts workflows in manufacturing facilities, disturbs the financial environment of the medical market, and distorts demand across sub-sectors of the healthcare industry. ${ }^{1}$

\footnotetext{
${ }^{1}$ In the experience of Asprime International Inc., a medical supplier to small and mediumsized government health facilities in the Philippines, there is considerable cross-categorical variation in supply sizes. Whereas devices directly related to the prevention, treatment, and rehabilitation of COVID-19 fall short, medical products unrelated to the global health crisis are oftentimes in surplus (A. Sanglay Jr., Personal Communication, January 24, 2021,).
} 
Manufacturers scrambling for limited raw materials struggle to assemble their workers in labour-intensive production, due to infections and regulations. Furthermore, labour disruptions along the international supply chain strain distributions of physical and human capital down the stream, an effect rippling in full circle across multiple sectors of the economy. Thus, it is impossible to disentangle pandemic-time labour, healthcare, finance, and welfare, as spheres of economic lives and ethical concerns.

On the demand side, the COVID-19 pandemic has forced consumers to alter their behaviours in significant ways that are likely to remain in the post-pandemic world, e.g., an increased focus on health and essential needs from housing and food to medication and hygiene (McKinsey, 2020), a rise in conscious consumption, and preferences for local and online spending (IBM, 2020). Worldwide, political decisions to close and reopen the economy have driven deep wedges between not only federal and state jurisdictions, church and state authorities (Hodge et al, 2020), but also communities of unequal wealth and power. Trapped in prolonged medical and economic uncertainties, consumers turn to medical products for survival. Unsurprisingly, the world has witnessed an explosive growth in demand for personal protective equipment (PPE) and hygiene products. For example, the global sanitizer market is expected to grow from USD 1.2 billion in 2019 to USD 2.14 billion by 2027, at a compound annual growth rate of $7.5 \%$ (FIOR, 2020). Meeting this demand requires mobilising productive capacities locally and enhancing the mobility of goods across tax and tariff regimes at a global level.

Whereas non-medical firms report fallen demand, reduced revenue targets, and downgraded capital expenditure plans, the Healthcare and Social Assistance industry is under pressure to grow, regardless of revenue adjustments (ISM, 2020). As a result, medical suppliers enter uncharted waters as they move to shift supply-chain planning, operations, and inventory management to sustain their output. Success is slow to come. At the start of the COVID-19 outbreak, the U.S. sounded alarm over its shortage of test kits and ventilators, for many essential raw materials and apparatus parts were imported from select geographic locations. As for PPE production, 90\% of the latex for sterile gloves is generated from Malaysia and a significant portion of surgical hand equipment are manufactured in Pakistan (NASEM, 2018). Therefore, global and local disruptions of both raw-material and equipment production have conspired to destabilise the global healthcare industry.

Although the COVID-19 reminds companies to revisit their global supply-chain strategy and adopt digital supply network capabilities, short-term actions often address the immediate crisis more effectively. Basic measures include educating employees on public health epidemiology, reinforcing screening protocols, and aligning IT support to adjusted work sites under evolving conditions. Companies that produce, distribute, or source from 
suppliers in impacted geographies may enhance their workforce, control Tier1 supplier risk, activate alternate sources, prepare for potential plant closures, conduct global scenario planning, and even leverage entity resolution platforms powered by artificial intelligence and machine learning to restructure data and illuminate supply networks. Companies that sell industrial products, commodities, or consumer products to crisis zones may adjust their short-term demand-supply synchronisation strategy, enable potential channel shifts, evaluate alternative inbound logistic options, enhance allocated inventories to ensure capability, and expand channels of communication with customers of diverse backgrounds and needs. Overall, it is important to render supply chain risks more visible, not less. Without a significant level of transparency, crisis-mitigation in pandemic times is an unlikely task.

\subsection{Medical Firms}

Since the outbreak of the COVID-19 pandemic in December, 2019 and its spread worldwide in 2020-2021, suppliers of medical products have taken the centre-stage of the global pandemic relief effort, first in China and East Asia, then around the world (Koley, 2021). Firms in the healthcare industry face a double challenge, for they must, at their own risks of COVID-19 casualties, quickly ramp up productions of not only mass-manufactured PPE, but also products typically transacted at slower paces and in lower quantities, such as expensive and durable ventilators. Notwithstanding their varied financing resources, all firms are driven by both a moral impetus and market incentives to expand all key factors of production: parts and components, labour and capital, plants and machines. For companies listed publicly, the flux and reflux in the public perceptions of their relevance to the epidemic cause their prices to ebb and flow. Unlisted companies, too, have to assess their strategies through multiple layers of prudential judgement in response to daily shifting signals from within the firm, the market, and the government. There is no way around maintaining labour standards and ensuring secure working conditions, since even automation-capable medical suppliers have only begun to explore, but cannot yet count on entirely contactless modes of production such as 3D-printing labs (Jamróz et al, 2018; Belhouideg, 2020). ${ }^{2}$ Furthermore, a supplier could not simply churn out five to ten times its usual output, should upper-stream firms fail to perform accordingly. Even the bestintegrated supply chain in a state of free association under sound supervision

\footnotetext{
${ }^{2}$ See also U.S. Food and Drug Administration (2017). "Technical Considerations for Additive Manufactured Medical Devices - Guidance for Industry and Food and Drug Administration Staff" (https://www.fda.gov/files/medical\%20devices/published/Technical-Considerationsfor-Additive-Manufactured-Medical-Devices---Guidance-for-Industry-and-Food-and-DrugAdministration-Staff.pdf).
} 
cannot organically scale up or down production with perfect precision and agility. Likewise, even the most watchful regulatory authorities are incapable of both smoothing out and stretching up a long supply chain without internal sacrifices and external support.

These supply-chain challenges offer reasonable grounds to question both the boastful claim of a golden opportunity and the premature call for a global calamity. A strategic approach, in contrast, is to leverage innovation for social responsibility in the midst of a healthcare crisis. The COVID-19 pandemic has witnessed accelerated, though at times chaotic integrations of local, regional, and international supply chains. It falls on both the private and public sectors to pursue this end in a systematic way. At the same time, firms benefit from prudential development more than profit-driven models, as they align growth with the cause of social good. The global public health crisis is a prime time for firms to project their identity and agency from a market actor to a social actor, both within and across the bounds of natural and artificial polities. There is no better time for entrepreneurships and corporations to return to the social, wherefrom their ancestors in the early-modern era emerged in the first place.

In this section, the paper zooms into 6 medical firms around the world which have played significant roles in the socio-political life of the 2019-2021 COVID-19 pandemic. As a first step, the paper identifies the effect of COVID19 on the financials and operations of these 6 publicly-listed firms: Mindray Medical International Ltd., Yuwell-Jiangsu Yuyue Medical Equipment \& Supply Co., Ltd., Beijing Aerospace Changfeng Co., Ltd, the Getinge Group, Medtronic plc, and Becton, Dickinson and Company.

Geographically, the first three firms are headquartered in China, with the majority of their clients based in the Asia-Pacific (Figure 2A). Whereas Changfeng is owned by the government, Mindray and Yuyue are private companies. Curiously but unsurprisingly, international observers of how Chinese authorities wielded extraordinary power to enforce stringent lockdowns in Hubei tend to ignore the crucial role of the ventilator-suppliers. The wealth of donated and purchased ventilators which enabled Wuhan to survive February 2020 as cases rose by $12.8 \%$ per day contrasts sharply with the dearth of respiratory devices across the U.S. and Southern Europe, two regions that outranked China in ventilator-manufacturing but suffered infection rates 3-4 times higher during scattered and repetitive outbreaks. As a result, whereas the municipality of Wuhan alone enjoyed no fewer than 16,900 ventilators in its worst days, the White House traded barbs with New York in April 2020 for stockpiling 800 ventilators in reserve, in addition to the 
6,500 deployed and the 4,400 secured from the federal government. ${ }^{3}$ From a humbler starting point in December, 2019, China has morphed into a formidable ventilator-exporter by 2021. In order to understand the social, political, and economic implication of this transformation, the paper analyses three Chinese firms of different types, sizes, and sectoral focuses.

Getinge and Medtronic are major medical firms headquartered in Europe, though over $60 \%$ of their sales are in non-European markets. Getinge is a leading Swedish producer of advanced ventilators, extra corporeal life support (ECLS) equipment, and monitoring devices for Intensive Care Units (ICU). To illustrate, by November 2020, Getinge had ramped up production to meet rising global demand, shipping an additional 16,000 ventilators worldwide, $160 \%$ above the approximately 10,000 machines it churned out in 2019 (Getinge, 2020). Getinge relies largely on traditional market financing tools to fund this expansion. It has, for example, issued a SEK 1 billion commercial paper within its COVID-19 Financing Framework, in line with the ICMA Social Bond Principles, but without having acquired a Second Party Opinion. ${ }^{4}$ Whilst Getinge's social value is plain to see in the COVID-19 context, its reputation for social impact predates the SARS-CoV-2: in 2019, Getinge was dubbed the Most Sustainable Company in the Life Science Industry by the World Finance magazine. Medtronic is an Irish med-tech firm and a global leader of ventilator production. Notably, on March 30, 2020, the Dublin-based ventilator-manufacturer publicly shared the design specifications of its Puritan Bennett 560 (PB 560), a compact, lightweight, and portable device for both clinical and individual use (Medtronic, 2020). Medtronic not only shared the basic design, but also ramped up the more sophisticated Puritan Bennett ${ }^{\mathrm{TM}} 980$ model, which boasts highly innovative breath-delivery technologies. Both as a strategy and for social good, Medtronic has built an impact beyond its traditional industrial, commercial, and geographical scope.

\footnotetext{
${ }^{3}$ See Brown, M. (1 April, 2020) "Fact Check: Does New York Have a Stockpile of Thousands of Unneeded Ventilators?" USA Today. The data on Chinese ventilators in Hubei is obtained from the National Health Commission in the People's Republic of China (Press release, 4 March, 2020).

${ }^{4}$ Key investors include Ramsbury Invest, Familjen Erling Persson Stiftelse, LKAB, Spiltan Fonder, Svenskt Näringsliv, Nordkinn Asset Management AB, and Swedbank Robur. See Getinge (April 17, 2020). "Getinge Issues SEK 1 billion COVID-19 Commercial Paper" (Press release: Gothenburg, Sweden).
} 
Figure 2A: Revenue Exposure by Geographical Region

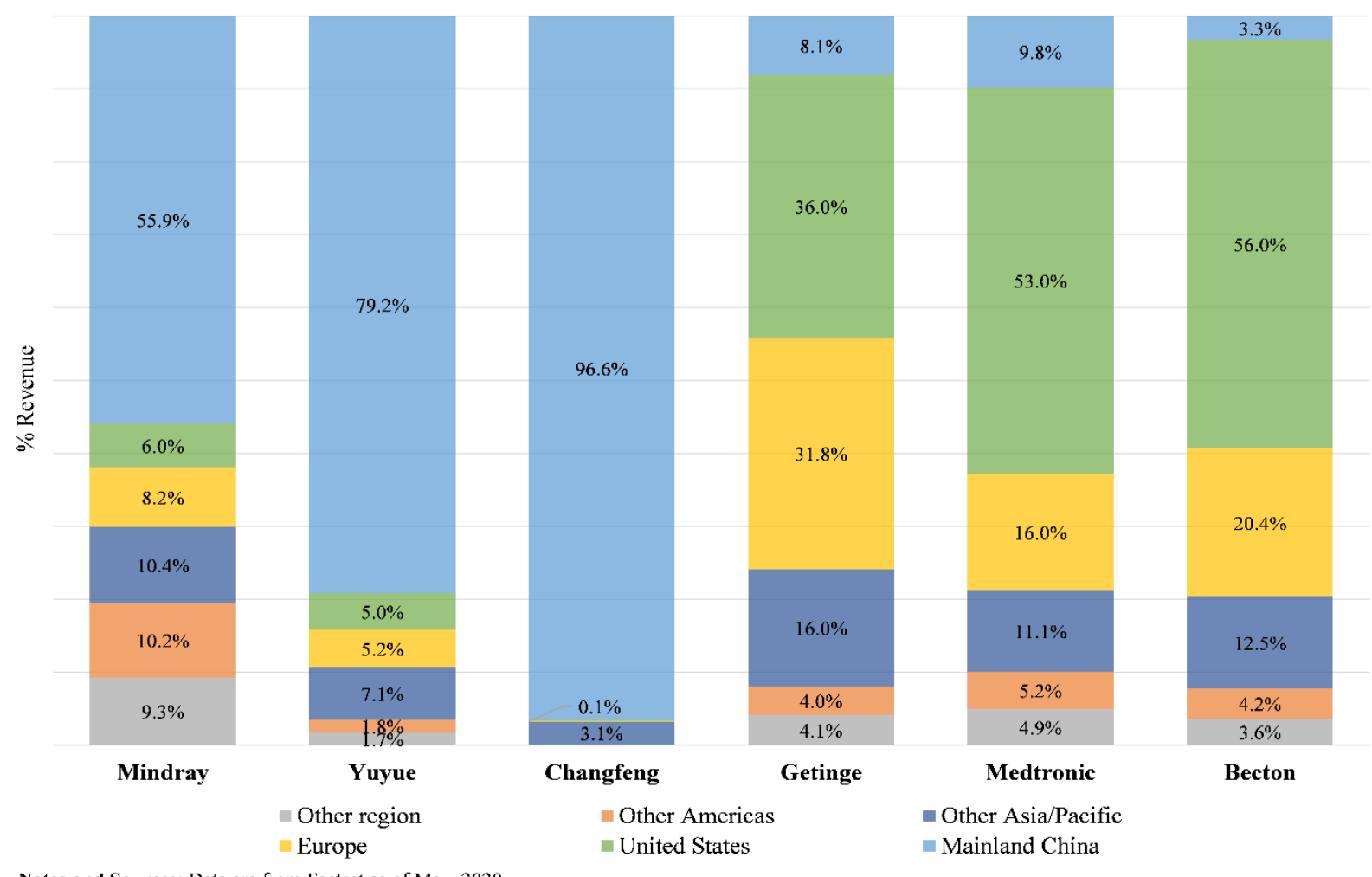

Notes and Sources: Data are from Factset as of May, 2020 
Figure 2B: Revenue Exposure by Sector

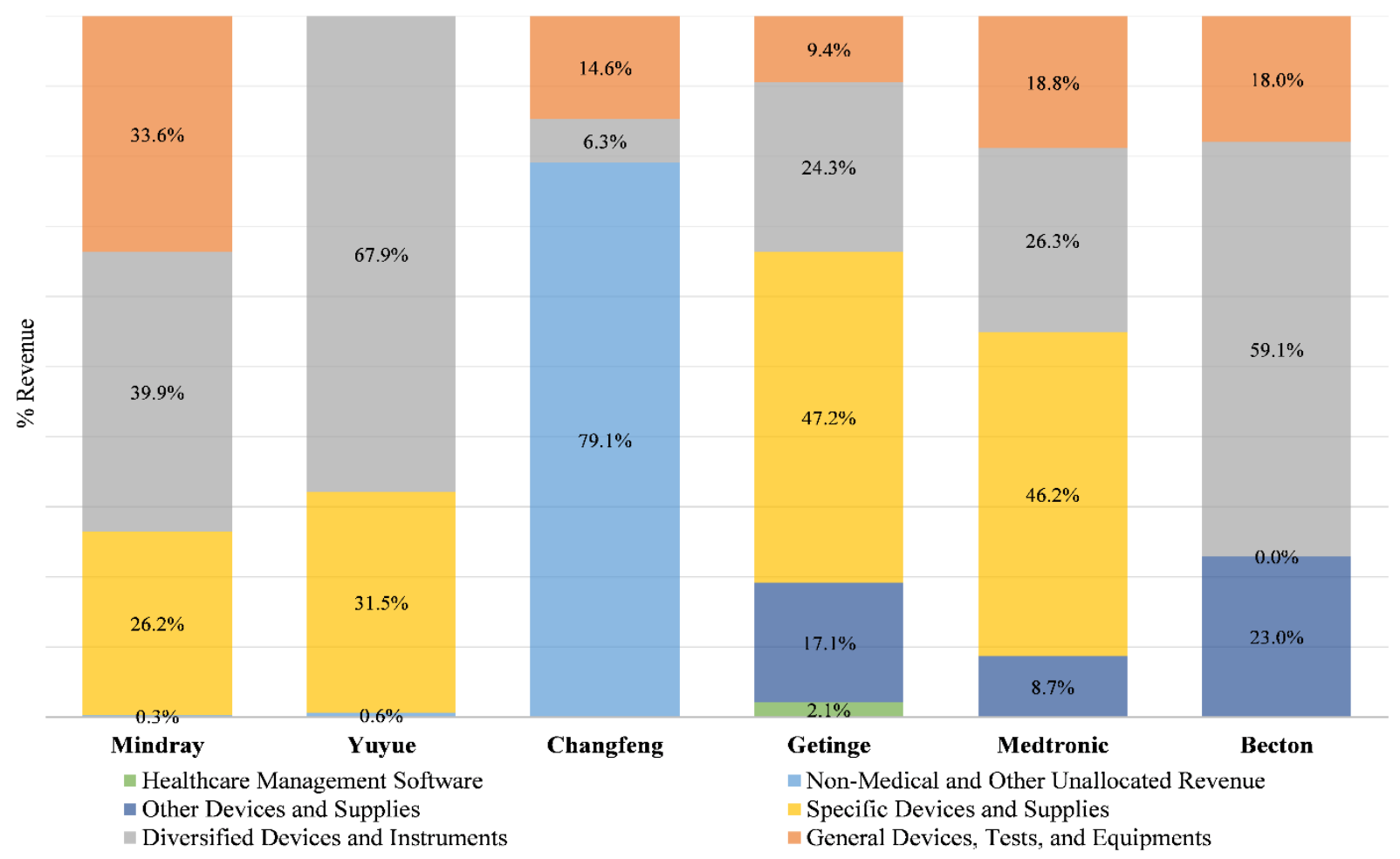

Notes and Sources: Data

"Specific Devices and Supplies" includes cardiology, neurology, vascular, respiratory, radiology,and sterilization devices. 
Becton is a versatile U.S. medical company that manufactures a range of critical medical products, from ventilators to test kits such as the BD Veritor ${ }^{\mathrm{TM}}$ Plus System, as well as syringes and needles for delivering COVID19 vaccines. By December 16th, 2020, the New Jersey-based med-tech giant had received over 1 billion orders worldwide. Becton sources financing widely, including a $\$ 24$ million investment from the U.S. Department of Defense, in collaboration with the U.S. Department of Health and Human Services, to bolster the productive capacity of test kits by $50 \%$ (BD, 2020). In sum, Becton is worth studying for its high relevance to COVID-19 relief across multiple sectors of the medical world.

In terms of service sectors, all but Changfeng derive the lion's share of their revenues from general medical devices, e.g., cardiology, orthopaedic, and surgical devices. In addition, they provide radiology and respiratory devices, safety supplies, diagnostic and drug delivery devices, as well as diverse healthcare services. The exception, Changfeng, is a governmentowned, high-tech enterprise that manufactures and markets computers, medical equipment, and pharmaceutical machineries (Figure 2B). Prior to the pandemic, it derived as much as $80 \%$ of its revenue from software and IT services. In 2020, however, Changfeng quickly transformed itself into a leading manufacturer of anaesthesia machines, respiratory devices, and oxygen supply systems, although its experience in making invasive ventilators remains limited.

\subsubsection{Effect on Stock Prices}

The effect of a public health crisis on stock prices has been a major topic of study in the field of economic history. For instance, scholars have sought to understand the 1918 influenza pandemic (the "Spanish Flu")'s general effect on US stock prices (del Ángel et al, 2021). Few, however, have examined the listings of medical firms. This paper zooms into the stock performances of 6 medical suppliers during the COVID-19 pandemic. Below, the chart shows stock price trends from the beginning of the pandemic to June 2021 (Figure 2C). The price was pegged to 100 on January $17^{\text {th }}, 2020$, as cases started to emerge outside China, in Bangkok and Kanagawa. ${ }^{5}$

\footnotetext{
${ }^{5}$ China reported the first Covid-19 death on Jan. 11, 2020 and published the genetic sequence of the novel coronavirus the following day. The first case ex-China was reported in Thailand on Jan. 13, 2020, followed by a second case 4 days later. In Japan, a COVID-19 case was identified on 16 January. And having arrived in the US on Jan. 15, an infected man visited an urgent care clinic in Snohomish County, WA on Jan. 19. See WHO (2020) "Listings of WHO's response to COVID-19 29 June 2020 Statement" \& "Novel Coronavirus (2019nCoV) SITUATION REPORT - 121 JANUARY 2020.”
} 
Figure 2C: Stock Prices (Indexed to 1/17/2020) ${ }^{1}$

6 Selected Firms

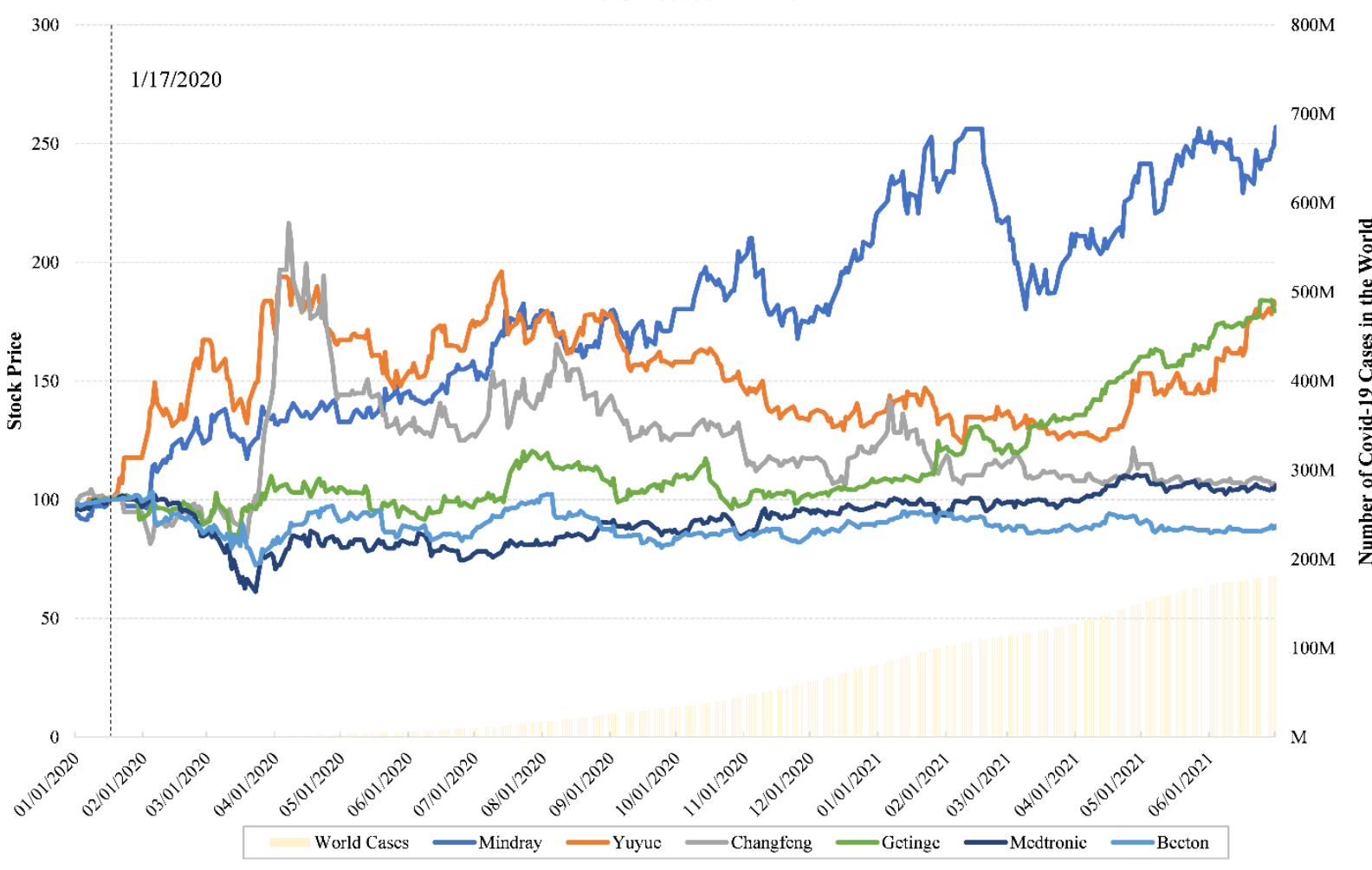

Notes and Sources: Data are from Factset as of June 202

${ }^{1}$ January 17 th, 2020 is the first Factset data entry on COVID-19 cases. The stock price is assumed to be 100 for all selected firms on this date. 
Social and financial uncertainties shook the medical market in late March, 2020, before a visible rebound worldwide, as the public and private sectors formed various coalitions to combat the medical emergency. Since then, Getinge's listings have tailed the quickening pulses of the European and American outbreaks, whilst Medtronic and Becton have exhibited more stability. Remarkably, Mindray has soared, from the Chinese to the global phases of the pandemic. The company has leveraged its international network to transition from its early focus on China to sales worldwide. Both in comparison and contrast to Mindray, Yuyue and Changfeng registered their best performance during the Wuhan crisis, given their revenue bases in China. Whereas the state-owned Changfeng levelled off as Hubei returned to a new normal, Yuyue witnessed a moderate second rise. A private company with a printed plan to engage with the North American market, Yuyue struggled to accomplish a speedy international expansion in the middle of an emergency, which requires an assemblage of industrial, commercial, and organisational preparation over time. However, as the pandemic persisted with no end in view, the company's pivot abroad and its newfound relevance to global public health have rallied to buoy its stocks. In sum, the three-way divergence of Chinese medical firms is associated with their different extents of global outreach.

\subsubsection{Effect on Financial and Operational Metrics}

A survey of financial statements shows how well the medical suppliers have coped with the COVID-19 crisis. First, growth in sales, or equivalently, growth in revenue, reflects a company's ability to generate income from its goods and services. In this way, all six firms have posted positive revenue growth rates over time. The Chinese firms registered moderate to successful performance during the Hubei phase of the crisis (Q1, 2020). Getinge performed increasingly well in Q2-Q3, 2020, as the centre of the epidemic shifted to Europe. Becton and Medtronic reported consistently low growth rates before the pandemic, but picked up their momentum from Q4, 2020 to Q1, 2021, as the crisis deepened in Europe, the Americas, and worldwide.

"Net income margin" or "profit margin," on the other hand, reflects how good a company is at converting revenue into shareholder profits. It is the percentage of revenue that remains after all operating expenses, interest, taxes, and preferred stock dividends have been deducted from the company's total revenue. The general trends in profit are consistent with revenue growths (Figure 2D). A few details, however, are worth noting. First, despite negative revenue growths when the pandemic first hit (Q1-Q2, 2020), Becton and Medtronic generated profits over time, as they kept their regular and emergency expenses under control. Second, Changfeng's profits ended high in Q1, 2021, despite negative revenues and sub-zero profits in Q1, 2020. 
Indeed, state-ownership is a double-edged sword. As a government-owned enterprise (GOE), Changfeng is both burdened with considerable adaptive costs and blessed with secure infrastructural support, hence its fluctuating performance throughout the pandemic. 


\section{Figure 2D: Revenue Growth and Net Profit Margin}

\section{Selected 6 Firms}
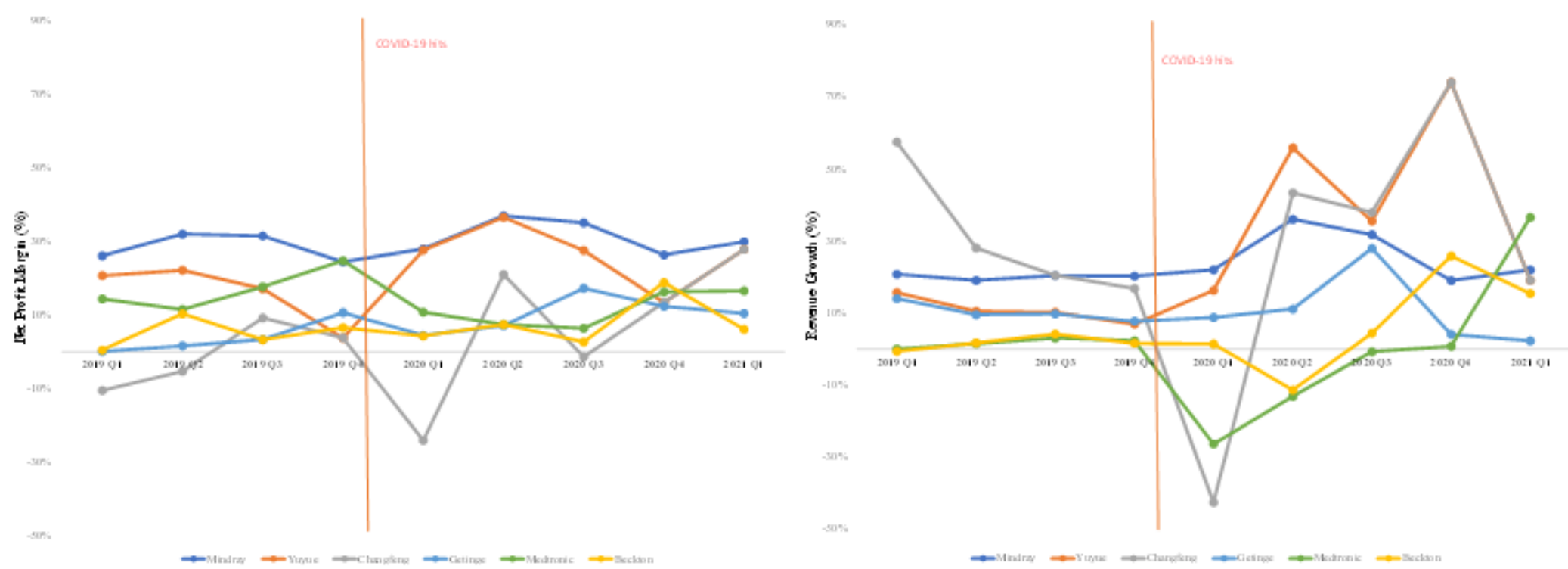

\section{Notes and Sources:}

Data are from FactSet Fundamentals. Medtronic data reflect financials as of a month later than the months indicated in the chart.

Yuyue and Changfeng have the same revenue growth (19\%) and net profit margin (28\%) in 2021 Q4. 
The chart below presents four additional metrics (Figure 2E). First, Mindray and Yuyue have both enjoyed increasing Return on Assets (ROA), an indicator of profitability relative to invested capital. They are followed by similar trends of smaller magnitude in Getinge and Becton, which also boast growing asset efficiency. Medtronic, with a sizable source of its revenue from cardiology surgical devices, and Changfeng, a primary producer of enterprise security management software, have both seen falling ROAs. Second, whilst Mindray, Becton, and Medtronic have experienced much less Asset Turnover Ratio (ATR) fluctuation than the volatile Changfeng, Yuyue and Getinge have seen their indicator of operational efficiency improve during the pandemic. Third, Getinge has exhibited higher Current Ratios (CR) than other firms until Q4, 2020 before a drastic decrease, suggesting both higher liquidity and potential risks of management inefficiency until Q1, 2021. Finally, the Net Debt-to-Equity (Net D/E) ratio shows all three Chinese ventilator-suppliers in the negative and their Euro-American peers in the positive. This metric reveals that whereas the Chinese firms enjoy more cash than liabilities over differently-sized assets, their counterparts and competitors in Europe and the U.S. resort to higher leverage-ratio financing tools early on in the pandemic. Becton and Getinge, however, both saw their debt-to-equity leverage fall over the course of the public health crisis. 


\section{Figure 2E: Financial Metrics and Ratios}

\section{Selected 6 Firms}
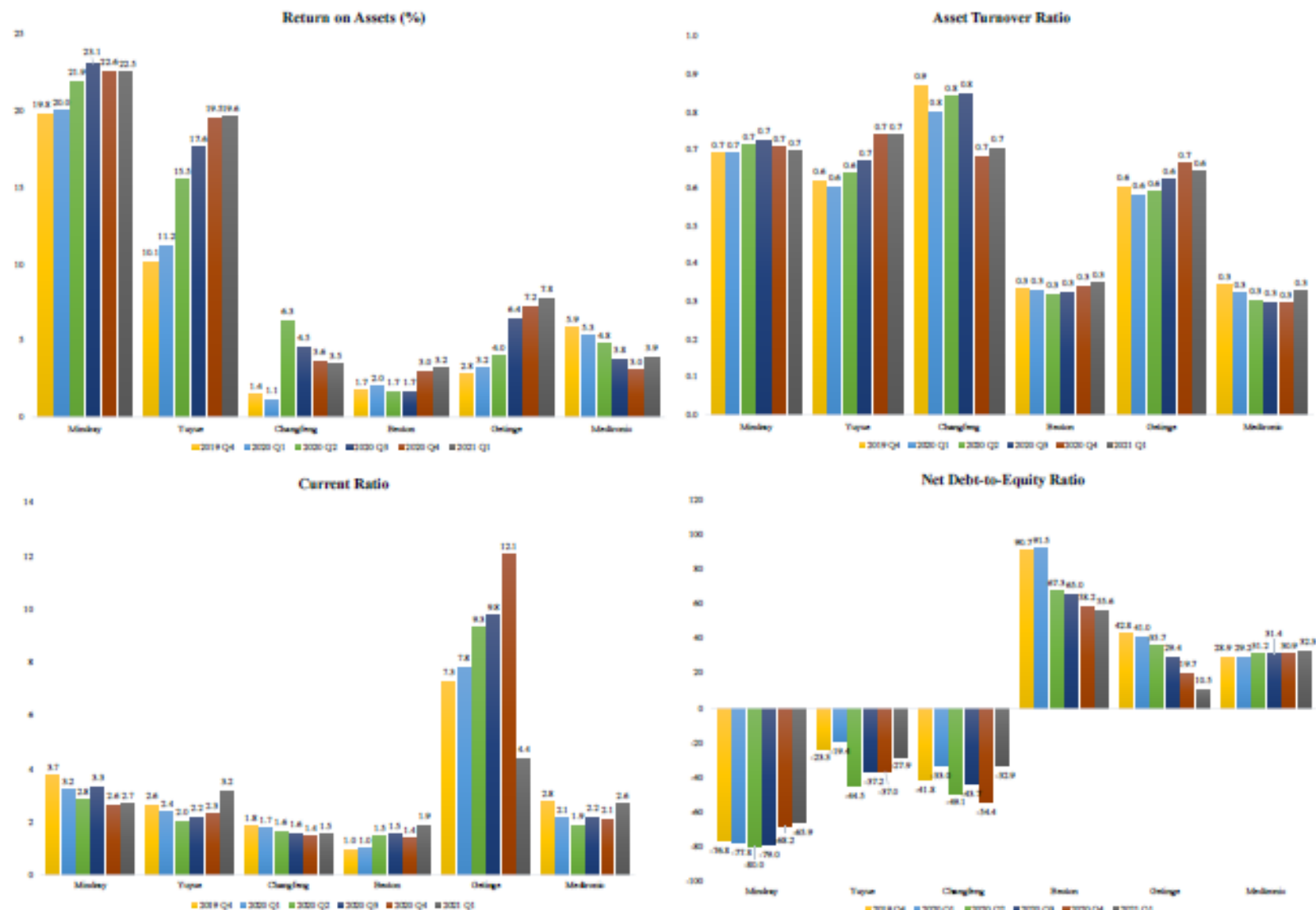

Notes and Sources: Data are from FactSet Fumdamentals. 
Overall, the case studies show that the performance of ventilatorsuppliers has shifted, not in mechanical response to the chart of COVID-19 cases, but across local ecosystems and global contexts. The paths of medical firms converge and diverge, given their pre-pandemic investments and market-shares, as well as their in-pandemic strategy and social responsibility. As the virus itself changes course, crisis-time performance is a function of both pre-crisis infrastructures and in-crisis judgements. The record of these medical firms demonstrates that, with the right set of core capabilities, it is not impossible to outperform the pandemic: adopting emergency measures that not only improve operational efficiency in the short-run but also optimise management in longer terms; addressing short-term obligations under the rubrics of larger visions; applying debt-to-equity leverage with moderation and downscaling it whenever necessary; communicating the company's social relevance to the public at the right points of time. Medical firms must build resilience not only to the severity but also to the mobility of the pandemic, which shakes conventional wisdom on management as a 'science.' For instance, a stringent supply-chain division and dispersion of labour based on local, regional, and national advantages (e.g., tax rates, local know-hows and expertise, concentration of raw materials, and corporate environment overall) may be rational but short-sighted in the healthcare industry. A skewed distribution of manufacturing sites, warehouses, and research investment could leave critical segments of the supply chain easily paralysed by an epidemic that strikes the world unevenly and unpredictably. Strategies in the global medical market, more than elsewhere, require not only rational assumptions, but also simulation, anticipation, and contextualisation.

\subsection{Distributors and Platforms}

Whilst many medical firms have either received orders via traditional means or processed purchases through corporate platforms (e.g., Getinge Online), customers from federal agencies and state governments to local hospitals, pharmacies, and healthcare providers have turned increasingly to specialised distributors to place their orders. Thanks to their expertise in information, security, and logistical management, distributing platforms are able to streamline the supply chain to reduce frictions, save time, and optimise value. By outsourcing distribution, manufacturers without logistical capacities of scale could save financial and human resources for research and production.

Digital platforms aim to match suppliers and consumers with precision and efficiency. Customers with various offering prices in hand and quantity demanded in mind count on algorithms to connect them with inventories from afar and to secure desired goods at an instant. A virtual agora where the voices of demand meet the promises of supply, platforms also help streamline, manage, and integrate the multi-stage, multi-sector, multinational medical 
supply chain. Suppliers of complementary components are mustered to complete a single order. Gaps in one region are filled by surplus from another. And needless to say, open information facilitates healthy competition, spurring firms to further specialise, self-position, and serve. Therefore, on both the supply and demand sides, platforms rightly boast their potential to form unlikely partnerships. It is of common interest that crisis-time connections acquire normative force after the tides of the pandemic recede.

As the COVID-19 pandemic ravaged the U.S., the 50 states emerged as some of the largest buyers of medical products. How and whence did their governments secure supplies? The paper reviews the transactions of New York, a state severely impacted by the spread of SARS-CoV-2. Below, it shows NY's top 25 contractors for medical supplies in the first two months of the pandemic, which account for $80 \%$ of all the medical supplies purchased by The Empire State (Table 1). This list did not change much throughout 2020: the top 9 vendors remained so by the end the year, notwithstanding minor shuffles in ranking. Most of the firms on the list are distributors and digital platforms. Most are based in New York, whilst others are from elsewhere in the United States, China, or Singapore. 


\section{Table 1: New York State Top 25 Contractors for Medical Supplies 2/1/2020 - 4/30/2020}

\begin{tabular}{|c|c|c|c|}
\hline Contractor & Location & Amount (\$mm) & Percentage \\
\hline DTM Healthcare Inc. & New York & 36.1 & $10.1 \%$ \\
\hline JCD Distribution Inc. & New York & 29.7 & $8.3 \%$ \\
\hline Zinntex LLC & New York & 19.8 & $5.5 \%$ \\
\hline Zhejiang Xinhongzhou Trading Co Ltd & China & 19.0 & $5.3 \%$ \\
\hline Suuchi Inc. & New Jersey & 17.4 & $4.9 \%$ \\
\hline Bespoke Fashion LLC & New York & 16.7 & $4.7 \%$ \\
\hline Thread Counsel Inc. & New York & 16.0 & $4.5 \%$ \\
\hline High Hope Group Jiangsu Tongtai Co Ltd & China & 15.0 & $4.2 \%$ \\
\hline New York Microscope Company Inc. & New York & 13.8 & $3.9 \%$ \\
\hline Sisloy LLC & N/A & 13.3 & $3.7 \%$ \\
\hline Staci Snider Designer & New York & 9.3 & $2.6 \%$ \\
\hline Designerkorner Inc & New York & 9.0 & $2.5 \%$ \\
\hline Dome International Inc. & New York & 6.8 & $1.9 \%$ \\
\hline Harper Scott LLC & New York & 6.8 & $1.9 \%$ \\
\hline Mcquade \& Bannigan Inc. & New York & 5.8 & $1.6 \%$ \\
\hline Adaptive Energy LLC & Michigan & 5.8 & $1.6 \%$ \\
\hline JK Private Stock Inc. & New York & 5.2 & $1.5 \%$ \\
\hline Foam Depot Inc. & New York & 5.2 & $1.4 \%$ \\
\hline Moomin Trading PTE. Ltd & Singapore & 5.1 & $1.4 \%$ \\
\hline Medtronic USA Inc. & Minnesota & 5.1 & $1.4 \%$ \\
\hline Midwest Biomedical Resources Inc. & Illinois & 5.0 & $1.4 \%$ \\
\hline And Luxe Inc. & New York & 4.9 & $1.4 \%$ \\
\hline Rusi Technology Co Ltd & China & 4.8 & $1.3 \%$ \\
\hline Zhejiang Materials Industry & China & 4.5 & $1.3 \%$ \\
\hline Boston Scientific Corp & Massachusetts & 3.8 & $1.1 \%$ \\
\hline Total & & 283.6 & $79.7 \%$ \\
\hline
\end{tabular}

\section{Notes and Sources:}

Data are from OpenBookNewYork.com.

To understand the unique obstacles and opportunities for New York's contractors, the authors conducted an interview with Suuchi Inc. (No.5 in Table 1), a digital innovator that only recently entered the healthcare industry. With an upsurge of COVID-19 cases in the country, Suuchi converted its fashion production lines into PPE frontiers. Although similar conversion stories abound, from retooled Tesla, SpaceX, GM, and Ford plants, to 
Somtech's turn from the rail industry to safety visors, and to the luggagemaker Wanxinda (WXD)'s pivot from travel accessories to KN95 masks, Suuchi's main contribution lies in its algorithm for streamlined distribution. Suuchi's global digital sourcing network, the GRID interface, not only connects 600 plus suppliers, manufacturers, and retailers worldwide, but also preloads the manufacturing process, quality check, packaging, and distribution, based on expected timelines. As a result, Suuchi is able to access clean and structured data as the basis for real-time actionable insights. Suuchi's innovations are not only technical, but also relational. First, as a business-to-business (B2B) mid-market enterprise solution, Suuchi positions itself as complementary to other types of digital platforms, e.g., Product Lifecycle Management (PLM) and Enterprise Resource Planning (ERP) tools. Second, by digitally transforming the tracking process, it systematised accountability throughout the supply chain. Third, an enlarged supply chain also enhances commercial security. By prioritising consistent and long-term agreements over separate and small-volume purchases, Suuchi leaves little room for intermediary agents to leverage the information transparency of digital platforms to re-sell products for profits in times of crisis and scarcity. ${ }^{6}$ This is especially a point of reference for the Chinese market, where reselling poses a threat to B2B ventilator transactions, a phenomenon checked only by the vigilant eyes of regulatory agencies.

\subsection{Innovation in a Public Health Crisis}

Scholarship has shown that on the one hand, crises impose budget constraint, financial uncertainty, managerial complexity, information insufficiency, and environmental ambiguity to innovative enterprises (Müller, 1985, Davis et al., 2009; Paunov, 2012). In gut responses, decision-makers typically act fast to cut down innovation investments irrespective of long-term consequences, e.g., slowing or stopping patent filings (Archibugi et al., 2013). On the other hand, it has been argued for generations that crises spur innovation (Schumpeter, 1934). Under logistical, financial, and social pressures, enterprises engage in more explorative than exploitative strategies, in order to radically adapt to unfolding realities (Levinthal and March, 1981).

Such a dual effect is also found in the COVID-19 pandemic. Medical firms resort to various combinations of productive, managerial, and financial innovations. As shown in the financial analysis, medical suppliers across the globe exhibit resilience in times of the pandemic, regardless of variations across geography, models, and institutional design. Additional frontiers of innovation may be the subjects of future studies. In technology, key areas for

\footnotetext{
${ }^{6}$ H. Li; Y. Wu \& B. Seo (June 30, 2020). Interview with Suuchi Ramesh, CEO and Founder of Suuchi Inc.
} 
innovation include (1) digital solutions and AI in remote monitoring, telemedicine, disease diagnosis, connected clinical trials, and contagion surveillance for epidemic management (2) additive manufacturing of 3Dprinted face shields, mask brackets, and components for powered air-purifying respirators or ventilator splitters (3) the application of responsive materials in diagnostic probes, sensors, and other elastomeric products (4) biomimicry and nanotechnology in epidemiological research, PPE-manufacturing, and even drug delivery systems (DDS).

In the context of a global pandemic, technological innovation carries not only empirical, but also normative weight. Improved efficiency of healthcare service amounts to added values of moral, social, and political efficacy. Next, this paper presents an ethical and economic case for revising and reforming the allocative algorithm of global distributing platforms, in order to better distribute critical supplies in the medical market.

\section{Part III. Pricing and Bidding of Medical Supplies: Toward a Need- Conscious Model}

Access to life-saving medical devices is a matter of ethical imperative and economic import. How is, and indeed, how should scarce ventilators be distributed amongst customers in variable needs? Could market mechanisms, ensuring equality and efficacy, ever align with the quest of justice? And what alternative models of allocating ventilators are within the limit of reason, if beyond the current walks of practices and shades of imagination? And what, after all, is an ethical and economical way to price, bid, and distribute scarce medical resources to a set of customers, either directly or through intermediary platforms? This question gives rise to more: should and could different conditions of need factor into the algorithm, so that a limited amount of medical supplies can be distributed to multiple buyers, based on not only how much they offer, but also how much they need? Can this goal be achieved through a normal auction, or does it require an alternative design? Is centralised planning necessary, or can a collaboration of public authorities and private platforms achieve a desirable outcome?

\subsection{The Cuomo Complaint: The Ventilator Bidding War in the United States}

By late March, 2020, an exponential infection rate in the U.S. resulted in a dire shortage of ventilators. Apart from delayed and aborted orders, occasional frauds and serious logistical barriers to cross-oceanic shipments further paralysed the supply chain, adding more heat to the air of simmering anxiety in New York. But befalling this spiral of confusion is what Governor Cuomo referred to as an "eBay-style" bidding war between the states, and indeed, between state governments and federal agencies. During his regular 
press briefing on March 31st, Cuomo bewailed a situation where New York, California, and Illinois bid for exactly the same item. In vivid details of verbalised imageries, Cuomo confirmed the economist's suspicion that what he censured at length was indeed an auction: the bid rose as state governments raised their offers, before Federal Emergency Management Agency (FEMA) outbid them all.

At first glance, the puzzle invites a simple solution in centralised rationing. Major hurdles, however, stand in the way. First, a rationing board has to derive its moral authority from near-universal participation of healthcare professionals and organisations, in the same way that a governing board derives its legitimacy to supervise a matching program of scarce organs from the participation of nearly all transplant surgeons (Applbaum, 2017). Second, exclusive or inclusive, government-rationing can neither eliminate nor even dominate market-based transactions of medical products, given the current structure of the global economy. Third, centralised rationing presumes the existence of medical stockpiles within nation-state borders, which runs against the common reality. Egalitarian in purpose or insensitive to disparity, any government has to recognise that the scarcity of medical resources is an international problem. Unless a transformative vision of internationalism underpins a structure of global governance that is capable of coercing nationstates into rationing medical supplies on an intercontinental scale, the triagebased rationing falls short of universalizability and fails to live up to its aspiration. This paper takes seriously the hurdles erected by nation-states against each other, as it addresses the obstacles in the flow of goods and services across global markets.

Bidders, as self-motivated seekers of the most and best resources to redress the impact of the pandemic, signal their willingness to pay in an auction, a mechanism designed to extract maximum surplus values. The current ventilator-bidding scheme resembles a first-price sealed-bid auction model, where bidders submit simultaneous sealed offers to the seller, and the highest bidder wins out to pay the stated value (Easley and Kleinberg, 2010). It is unwise to count on this normal process for resource-allocations in a crisis, but an intuitive charge of inequity is not enough. In fact, conflicting proposals for how to allocate scarce resources (e.g., ventilators) have flared up time and again in the course and aftermath of the COVID-19 pandemic (BlumenthalBarby et al, 2020). Recent studies on the distribution of ambulances during the COVID-19 pandemic shows that it is unrealistic to rely only on the selfrestraint of self-interested agents to distribute and redistribute scarce healthcare resources in an equitable way (Du Pont and Baren, 2020). That is, intervention - either by institutions of public authority or through mechanisms of private exchange - is necessary for the ethical and efficient allocation of ambulances and ventilators. And since centralised power alone cannot deliver 
critical medical supplies across the globe, a more pragmatic approach is to convert the appeal to a robust demand of healthcare ethics into a viable pricing and distributing mechanism.

\subsection{Proposed Price-Based, Need-Conscious Bidding}

So far, moral theorists approach the distribution of medical resources in pandemic times through age-old 'egalitarian,' 'utilitarian,' or virtue-ethics paradigms. In spite of the "ineluctable need to prioritize the needs of the many," some bioethicists erect a false dialectic between egalitarian and utilitarian ideas with the statement that "there are no egalitarians in a pandemic" (Savulescu et al, 2020). In fact, the task at hand is to design a distributive algorithm to provide healthcare to not only the vastest, but also the most vulnerable demographics. In this light, such labels as 'utilitarianism' and 'egalitarianism' offer neither any configuration of 'utility' nor a framework of 'egality.' That is, how many units of fictional 'utils' or relative 'egals' on earth does the public sphere gain by allocating an additional ventilator to one neighbourhood over another? The question cannot be answered by ethicists or economists alone, but only from a mixed perspective, and with a view to applications in the medical market.

Other liberal ethicists approach the distributive justice of medical resources by balancing 'egalitarian' and 'utilitarian' appeals. For example, it is both 'utilitarian' and 'egalitarian' to make distributive decisions by 'maximising life expectancy' (Stein, 2002). Such a solution is sound in principle but difficult to execute in mass-scale resource transfers, for it is impossible to calculate the aggregate years to be saved at the hands of every single bidder in each locality. In truth, the moral urgency of the pandemic makes it necessary to revise, rather than renounce, existing market mechanisms such as bidding platforms, before it is possible to overcome them.

This paper proposes the following distributing algorithm that incorporates the variable of need, in addition to offering prices and demanded quantities.

Define:

$p$ : the dynamic price offered, the primary indicator of bidder-competitiveness in the auction

$q$ : the order amount in a given bid, assuming a general shortage of supply $n$ : the degree of need, which is itself a function of an assemblage of factors:

a) the cumulative number of confirmed cases and deaths in a given region

b) the projected infection rates, based on data and demographics, such as the density of population, frequency of interstate and international travel, and proximity of major transport hubs: ports, stations, airports 
c) the number of healthcare facilities and their capacities, measured by the size of ICU staff and capacity, such as rooms, beds, and ambulances.

d) the current size of the concerned supplies in use and stockpiles in reserve, if any.

The need-conscious approach, in its basic structure, requires the following steps.

(1) Let $\left\{B_{i}\right\}, i=\{1,2, \ldots N\}$ be the set of ventilator-bidders on the platform at a given point in time. For each $B_{i}$, let their bidding prices, quantities requested, and need level be $p_{i}, q_{i}$ and $n_{i}$, respectively.

Let $p_{0}=\sum_{i=1}^{N} \quad p_{i}$ be the price benchmark, i.e., the average of all offering prices.

Let $n_{0}$ be the benchmark for need, i.e., the national or international level of need. ${ }^{7}$

Let $S$ be the amount of ventilators the platform has in stock at a point in time.

(2) For each buyer $B_{i}$, standardise $p_{i}$ and $n_{i}$ against the benchmarks $p_{0}$ and $n_{0}$. Assign equal weights to the standardised scores and calculate a composite score for each buyer.

(3) Standardise the composite scores to obtain a distribution of scores $\left\{b_{i}\right\}$ amongst the buyers, where the mean equals 0 and standard deviation equals 1 . Note that roughly $99 \%$ of the standardised composite scores should be between -3 and 3 .

(4) If the total quantity requested is smaller than the total amount of ventilators in stock, i.e., $\sum_{i=1}^{N} \quad q_{i}<S$, then each buyer receives the quantity requested:

$$
Q_{i}=q_{i}
$$

(5) If the total quantity requested is greater than the total amount of ventilators in stock, i.e., $\sum_{i=1}^{N} \quad q_{i}>S$, then proceed to the allocating algorithm:

(a) First, compute $b_{i}^{\prime}=b_{i}+3$. This way, $99 \%$ of $\left\{b_{i}^{\prime}\right\}$ would fall between 0 and $6 .^{8}$

(b) For each $i$, the allocation would be:

$$
Q_{i}=\frac{b_{i}^{\prime} \cdot S}{\sum_{i=1}^{N} b_{i}^{\prime}}
$$

(c) If $Q_{i}<q_{i}$, then buyer $i$ is temporarily "in deficit". $Q_{i}$ would be the final amount assigned to buyer $i$ in this round.

\footnotetext{
${ }^{7}$ The national or international benchmark is determined by steps a-d using world statistics.

${ }^{8}$ This ensures that $99 \%$ of the buyers receive a positive amount of ventilators.
} 
(d) If $Q_{i}>q_{i}$, that is, the amount allocated to buyer $i$ is greater than the quantity requested, then there is a surplus for buyer $i$. Sum up the total surplus from all buyers, and allocate it among the buyers "in deficit" the same way we did it before:

$$
Q_{i}^{\prime}=\left(\frac{b_{i}^{\prime} \times I\left(Q_{i}<q_{i}\right)}{\sum_{i=1}^{N} b_{i}^{\prime} \times I\left(Q_{i}<q_{i}\right)}\right) \cdot \sum\left(Q_{i}-q_{i}\right) \times I\left(Q_{i}>q_{i}\right)
$$

(e) Iterate this process until there is no surplus to allocate further. If buyer $i$ is still "in deficit" at the end of this process, it needs to find additional supplies to fulfil the remainder of the need.

(6) If bidders drop out, let the freed-up quantity be added to the amount of $S$ and allocated to the remaining buyers according to the calculated distribution of $\left\{b_{i}^{\prime}\right\}$.

The following chart presents a simulation study with 10 Buyers and $\sum_{i=1}^{N} \quad q_{i}>S$.

\section{Table 2: Simulation Study with 10 Buyers - An Example}

\begin{tabular}{|c|c|c|c|c|c|c|c|c|c|c|c|c|}
\hline Buyer & $p_{i}$ & $q_{i}$ & $n_{i}$ & $b_{j}$ & $b_{i}^{\prime}$ & $\begin{array}{l}\text { 1st Round } \\
\text { Allocation }\end{array}$ & $Q_{i}^{\prime}$ & $\begin{array}{l}\text { 1st Round } \\
\text { Surplus }\end{array}$ & $Q_{i}^{\prime \prime}$ & $\begin{array}{l}\text { 2nd Round } \\
\text { Surplus }\end{array}$ & $\begin{array}{c}Q_{i}{ }^{\prime \prime} \\
\text { (Final) }\end{array}$ & $\begin{array}{c}\% q_{i} \\
\text { Realized }\end{array}$ \\
\hline 1 & 46,642 & 70 & 7 & 1.73 & 4.73 & $16 \%$ & 236 & 166 & 70 & 0 & 70 & $100 \%$ \\
\hline 2 & 24,292 & 190 & 2 & -0.61 & 2.39 & $8 \%$ & 119 & 0 & 148 & 0 & 148 & $78 \%$ \\
\hline 3 & 13,247 & 223 & 1 & -1.36 & 1.64 & $5 \%$ & 82 & 0 & 101 & 0 & 102 & $46 \%$ \\
\hline 4 & 40,619 & 300 & 5 & 0.80 & 3.80 & $13 \%$ & 190 & 0 & 235 & 0 & 236 & $79 \%$ \\
\hline 5 & 47,883 & 251 & 2 & 0.44 & 3.44 & $11 \%$ & 172 & 0 & 213 & 0 & 213 & $85 \%$ \\
\hline 6 & 34,914 & 207 & 4 & 0.40 & 3.40 & $11 \%$ & 170 & 0 & 211 & 4 & 207 & $100 \%$ \\
\hline 7 & 14,372 & 270 & 3 & -0.84 & 2.16 & $7 \%$ & 108 & 0 & 134 & 0 & 134 & $50 \%$ \\
\hline 8 & 14,414 & 84 & 6 & 0.12 & 3.12 & $10 \%$ & 156 & 72 & 84 & 0 & 84 & $100 \%$ \\
\hline 9 & 19,436 & 81 & 1 & -1.30 & 1.70 & $6 \%$ & 85 & 4 & 81 & 0 & 81 & $100 \%$ \\
\hline 10 & 40,760 & 298 & 4 & 0.62 & 3.62 & $12 \%$ & 181 & 0 & 224 & 0 & 225 & $75 \%$ \\
\hline Total & & 1,974 & & & & & 1,500 & & 1,500 & & 1,500 & \\
\hline
\end{tabular}

Notes and Sources: Results in this table are generated assuming the following parameters: $\mathrm{S}=1500, \mathrm{~N}=10, p_{0}=29,658, n_{0}=3$. Offering prices are randomly generated from $\$ 10,000$ to $\$ 50,000$. The order amounts are randomly generated from 50 to 300 .

This simulation study showcases the merits of the revised algorithm (Table 2). First, the introduction of the need factor costs the suppliers some surplus value otherwise to be extracted from the highest price-caller, but leaves them enough surplus in the moderated auction, even beyond prepandemic market prices. Second, although the willingness to buy at higher prices $(p)$ already signals urgency to some extent, there is no way to safeguard the interest of those in greatest need unless $n$ factors into the formula. Third, the price-based and need-conscious platform incentivises its customers to cooperate. An algorithm that defies the 'winner takes all' logic discourages 
bidders from driving the price up to exorbitant levels. Fourth, suppliers are able to leverage the price-based and need-conscious algorithm's generalisability, credibility, reasonable profitability, and last but not least, the moral appeal of sensitivity to need in a public health crisis. There is, however, one point of caution and complication. The simulation illustrated above reflects only snapshots of a dynamic bidding process. In reality, all variables including the benchmarks are constantly changing, as the epidemic evolves over time.

This price-based but need-conscious model outperforms conventional auctions in both efficiency and ethics. Efficiency-wise, whereas most auctions allow bidders with deeper pockets but lower need to outbid slightly less competitive offers with greater need, the revised model ensures that the needier and neediest do not walk away empty-handed. In ethical terms, the new algorithm recognises need and the needy as a factor in the distribution of life-saving resources. This formal recognition is significant, for it confers respect to the needier in search of health and safety, hence social freedom (Taylor, 1992; Butler, 1997; Honneth, 2018). In a hypothetical scenario, even if the neediest happen to win out in a need-insensitive auction, they suffer unrecognition by the platform-a virtual space of sociability.

The ethical and economic implications of the need-conscious algorithm apply generally to individuals, social groups, and public institutions. But in the particular context of U.S. states - to briefly return to Governor Cuomo's concern - three types of state governments may benefit from the revision of the algorithm: (1) states with high need but low purchasing capacities (2) moderately wealthy states that request a large quantity at uncompetitive prices (3) states outbid in opaque bidding processes. At a time when unqualified ventilator-sellers, from Dome International to Yaron OrenPines and Segev Binyamin, exploit the rhetoric of emergency 'ethics' against auction 'economics' in pursuit of illegitimate profit, it is crucial that platforms maintain the highest level of security, transparency, and accountability. ${ }^{9}$

Scholars are right to observe, based on epidemiological experiences prior to the COVID-19 crisis, that the "combination of constrained resources

\footnotetext{
${ }^{9}$ Frauds prevail also because under enormous pressure, state governments have relaxed the normal procedures of regulation in order to expedite purchases of medical supplies, i.e., "No. 202: Declaring a Disaster Emergency in the State of New York": by Section 29-a of Article 2-B of the Executive Law, Governor Cuomo suspended Section 112 of the State Finance Law, Section 163 of the State Finance Law and Article 4-C of the Economic Development Law "to the extent necessary to allow the purchase of necessary commodities, services, technology, and materials without following the standard notice and procurement processes"; Section 97G of the State Finance Law; Section 359-a, Section 2879, and 2879-a of the Public Authorities Law "to the extent necessary to purchase necessary goods and services without following the standard procurement processes."
} 
and increasing demands" disrupts normal procedures of prioritisation, from market exchange to institutional rationing (Lopez-Casasnovas and Pellise, 2016). Whilst a variety of conventional approaches, from the business ethics of corporate social responsibility to the economic tools of nudges and subsidies lend themselves to fight the pandemic, the key is to neither leave market practices unfettered, nor concentrate all distributive power in a few bureaucratic hands. Rather, to factor local need into globally integrated distribution obtains the best of both worlds.

\section{Part IV. Medical Trade in the Global Political Economy}

The ethics and economics of medical supplies are situated in global contexts of political economy: trade and tariff, geopolitics and diplomacy, international relations and global governance.

If public health and macroeconomics are 'symbiotic' (Smith et al, 2016), then international medical trade is a key mechanism of their obligate mutualism. Since nation-states depend on the free flow of medical goods across tariff regimes, macroeconomists have unsurprisingly called for loosening or suspending tariffs on medical imports. Broadly speaking, the free-trade solution to medical shortage calls for the following measures: (1) raise the burden of proof for sustaining import taxes or quotas (2) to dismantle some, if not all import licensing requirements and "buy local" requirements (3) optimise and enforce terms of trade agreements to reduce the risks faced by foreign suppliers; (4) maintain these standards for longer durations of time even after the initial waves of the pandemic recede (Evenett, 2020). Of course, a lower barrier to medical trade is conducive to moving supplies across nationstate borders in the midst of a global pandemic that recognises no human territoriality.

But frictions persist. First, when import facilitations meet export obstructions, an expedient tariff regime may not be reciprocated with a favourable export policy. Second, there are increasing logistical and opportunity costs in overseas shipping, especially when the world's major manufacturing exporters are amongst the first and hardest hit by the pandemic. A freer trade may not, in such a case, deliver a faster trade. Third, mounting logistical difficulties may convince distributing platforms to shift to local producers. Even global distributors seek to assemble a robust and resilient local supply chain to supplement, if not outright replace their international supply chains. Fourth, the geopolitics of a global pandemic inevitably raises tensions that may spill into commerce. Although scholars are still clarifying the wildlife causes of the 1918 influenza pandemic (Taubenberger et al, 2005; Tumpey et al, 2005), public figures waste no time to weaponize the alleged 
origins of epidemics in geopolitical rhetoric. ${ }^{10}$ The Sino-American medical trade took tolls in the 2017-2019 Trade War before a resurgence during the pandemic. Furthermore, at the height of the American public health crisis, the Congressional Research Service recommended further reduction of US reliance on Chinese medical supplies. Therefore, it is unlikely that a blanket call for free medical trade would pass the scrutiny of political forces at home (Sutter et al, 2020). Fifth, even if both export and import policies are favourable, suppliers may be under pressure to prioritise domestic customers. Internationally, governments may instruct them to favour certain clients over others. In the midst of chaos, firms may also offer deals at fluctuating prices or through untransparent procedures. Overall, the free-trade intuition meets a motley of obstacles in pandemic times. Whilst protectionist sentiments and stiff trade policies do stand in the way of delivering medical supplies to frontline healthcare professionals, it is unclear how trade policy reform could enable "medical supplies to get to where they are needed most" (Evenett, 2020). Refining trade environments, optimising logistical efficiency, and ensuring distributive justice are three distinct issues that are correlated and codependent, but not linked through causal mechanisms. Therefore, they cannot be coalesced, but only coordinated.

\subsection{From H1N1 to COVID-19: Comparing Shifts in U.S. Medical Reliance}

Whereas it is common knowledge that both trade policies and epidemic diseases alter the outer shape and inner life of public health, much less understood is the effect of a trade war on a pandemic war. This section compares how US medical reliance has shifted throughout the 2009 H1N1 Influenza A Pandemic vs the 2019-2021 COVID-19 pandemic.

The influenza H1N1pdm09 epidemic, popularly known as the Swine Flu, serves as a point of comparison for the SARS-CoV-2 pandemic both in nature: origin, evolution, and epidemiology, and in culture: disease-detection, surveillance, and reporting (Relman et al, 2010). The scatterplots below reveal considerable differences in their impacts on medical reliance (Figure 4A-4B).

\footnotetext{
${ }^{10}$ Senator John Coryn of Texas has claimed that MERS (Middle East Respiratory Syndrome), first detected in the Arabian Peninsula, and the Swine Flu (H1N1 influenza), first identified in North America, originated in China where people consumed "bats and snakes." See Centers for Disease Control and Prevention Government agency (CDC). "Middle East Respiratory Syndrome (MERS)" (https://www.cdc.gov/coronavirus/mers/index.html) \& "2009 H1N1 Pandemic (H1N1pdm09 virus)" (https://www.cdc.gov/flu/pandemic-resources/2009-h1n1pandemic.html).
} 
Figure 4A: Share of US Import from Selected Countries ${ }^{1}$

H1N1: April 2009 vs. April 2010²

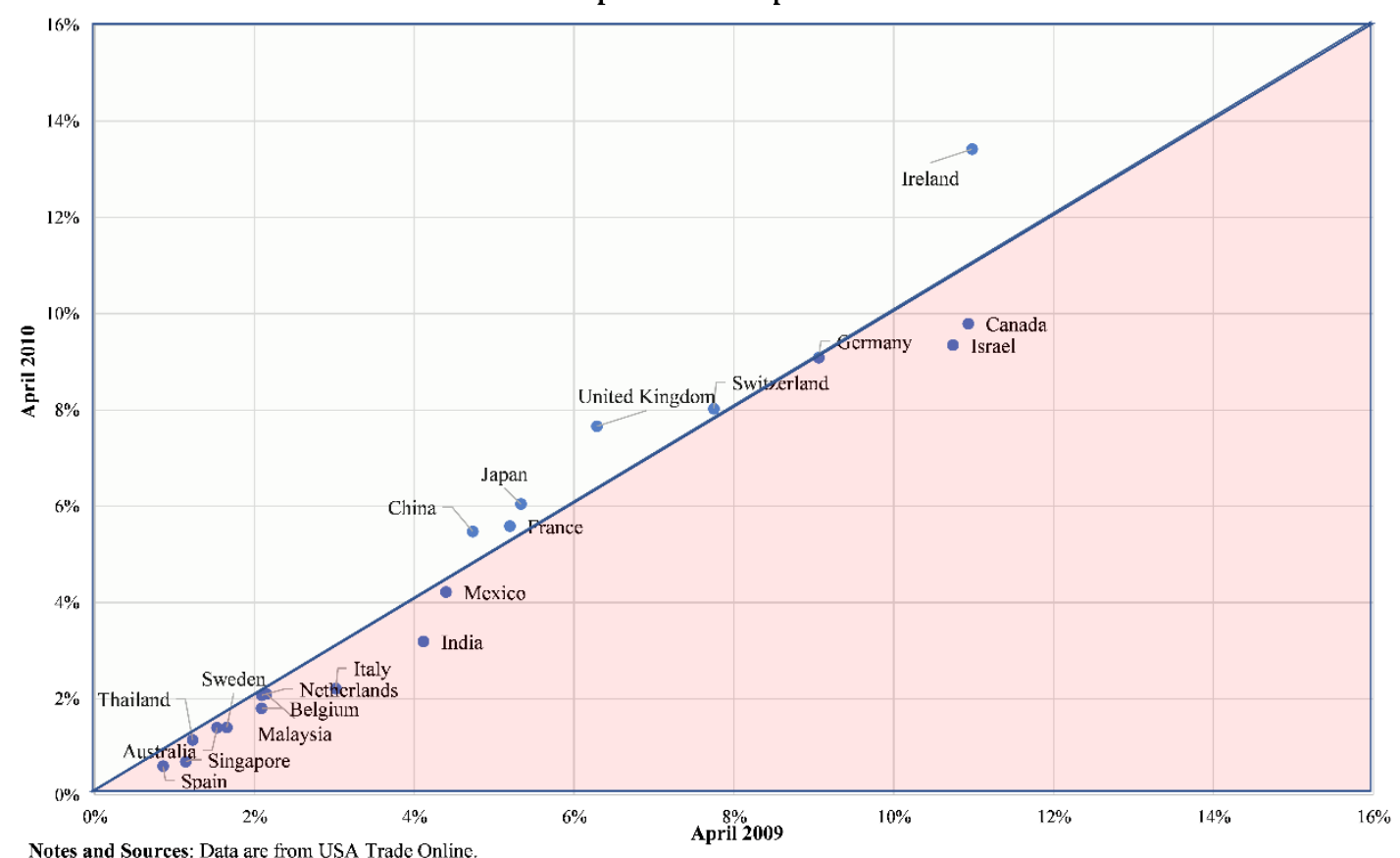

Notes and Sources: Data are from USA Trade Online.

' This exhibit shows the top 20 countries from which U.S. imported medical supplies as of April 2009

${ }^{2}$ April 2009 indicates the time of the first confirmed H1N1 case. April 2010 indicates the beginning of the slow down after the major waves of H1N1. 
Figure 4B: Share of US Import from Selected Countries ${ }^{1}$ COVID-19: January 2020 vs. March 2021 ${ }^{2}$

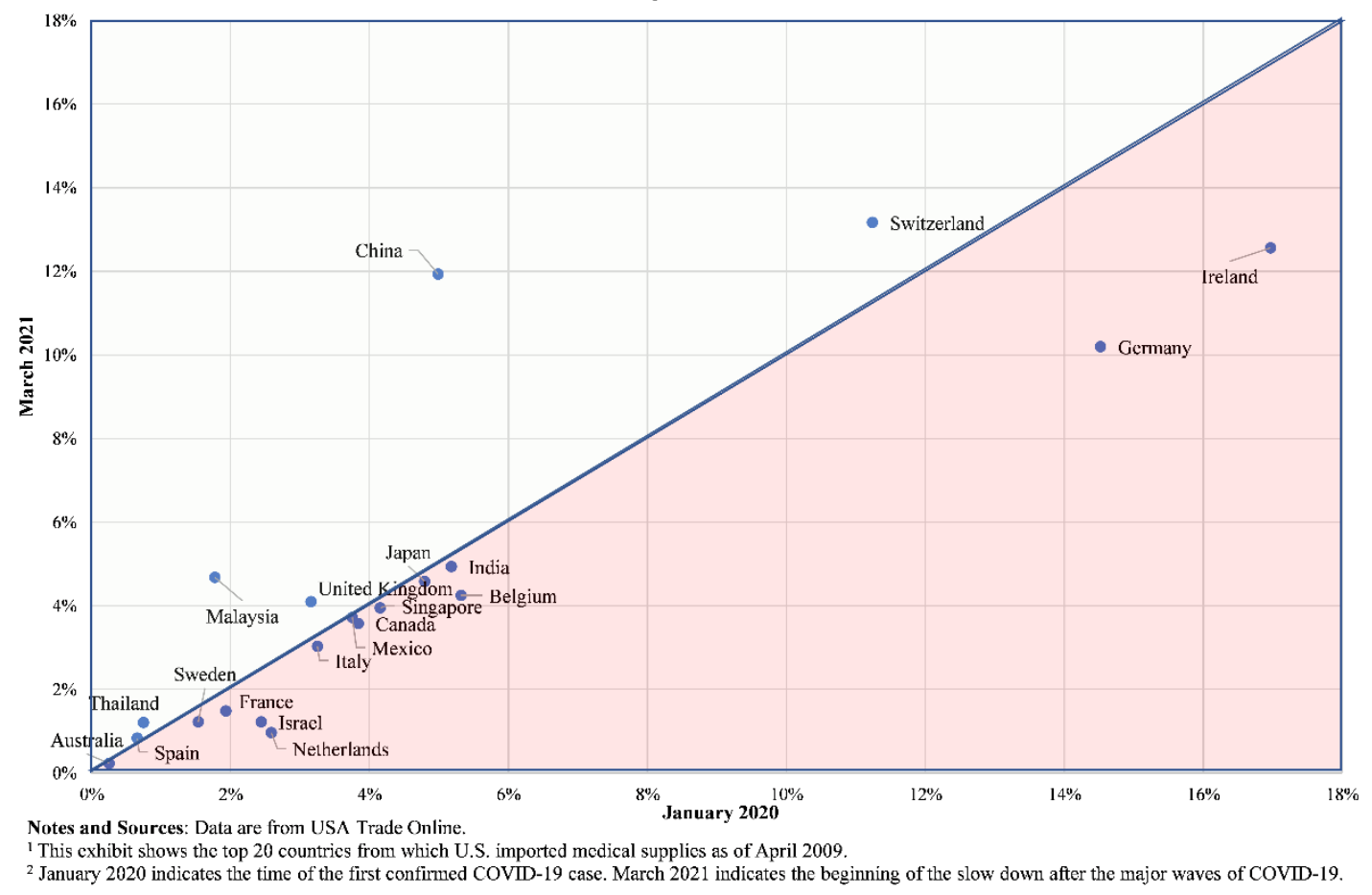

The scatterplots identify a union of $\mathrm{H} 1 \mathrm{~N} 1$ and COVID-relevant medical supplies, as represented by 45 Harmonised System (HS) codes. The scatterplots showcase the top 20 countries, which have remained largely consistent since 2009. It is clear that the major medical exporters to the U.S. are consistently Ireland, Germany, Switzerland, and China. But there are noticeable differences between the two pandemics. The U.S. mildly and evenly boosted import from Ireland (+2\%) and elsewhere to combat the H1N1 outbreak, but has been unable apply this strategy against the COVID-19 (-4\%). Whereas import from China grew moderately in $\mathrm{H} 1 \mathrm{~N} 1(+1 \%)$, it increased drastically in the fallout of COVID-19 $(+7 \%)$. In other words, willing or unwilling, the U.S. has counted on surplus Chinese medical products as a main trade instrument to combat the COVID-19.

\subsection{From Trade War to COVID-19: Impact of Trade Conflicts on Pandemic Preparedness}

The U.S.-China Trade War and the COVID-19 pandemic have dealt a double blow to the global economy. These two crises, one cultural and one natural, have co-evolved in the overlapping realms of health and economic policies. A key question is, has the Trade War affected the flow of PPE, 
medical apparatus, and diagnostic kits across the Pacific, before the U.S. declared war on Coronavirus in March, 2020? If so, since when, in which categories, and to what extent? By analysing both historic and recent data (2008-2021), this paper argues that although US medical imports grew rather than shrank as Sino-US tensions escalated, new tariffs closed down American access to Chinese medical supplies, which turned out to be critical resources during the pandemic. Due to the fortuitous timing, the U.S. has both weakened its pandemic preparedness by 2020, and failed to shift medical reliance away from China to other Asian and European suppliers by 2021.

The 2019-2021 data from the United States Census Bureau (USCB) show that China's share in U.S. medical imports slumped to a historical 2.6\% in March 2020, before a dramatic rebound to the unprecedented height of $12.4 \%$ in March, 2021. In 2019, though, China was still the third-largest exporter of medical supplies to the U.S. ( $\$ 12$ billion), after Ireland and Germany. About $8.4 \%$ of U.S. import of COVID-relevant medical products came from Mainland China. Historically, the share climbed between 2009 and 2014 , before a slow and a steady decline since 2016 . The larger story here is America's gradual reduction of reliance on Chinese medical supplies over a decade. ${ }^{11}$ However, in the COVID-19 context, one must further classify different medical products to track subtler trends. US medical import of Chinese diagnostic test kits (including diagnostic reagents and clinical instruments for in Vitro Diagnostics), hygiene, syringe \& needles, medicaments, vitamins, and medical consumables, as well as smaller goods from antibiotics and Hydrogen peroxide to bandages and cotton sticks have (1) remained stable, despite small dips, during the Trade War (2) increased during the COVID-19 pandemic. China's share in US intakes of PPE, medical apparatus (including ventilators: patient-monitoring, and X-Ray devices), and thermometers, however, plummeted during trade disputes, before bouncing back after the COVID-19 outbreak in North America (Figure 4C). Clearly, the Trade War reshaped the structure of U.S. medical import, with visible impact on its access to Chinese supplies. Once it became obvious that pandemicafflicted exporters such as Germany, Singapore, and Ireland could no longer substitute for Chinese suppliers, the U.S. reversed its policy of reducing Chinese medical import.

\footnotetext{
${ }^{11}$ The paper selects Singapore and Germany as China's foils: No.1 and No.2 exporters of ventilators to the U.S., followed by China at the third place.
} 
Figure 4C: Share of US Total Import

01/2008-04/2021
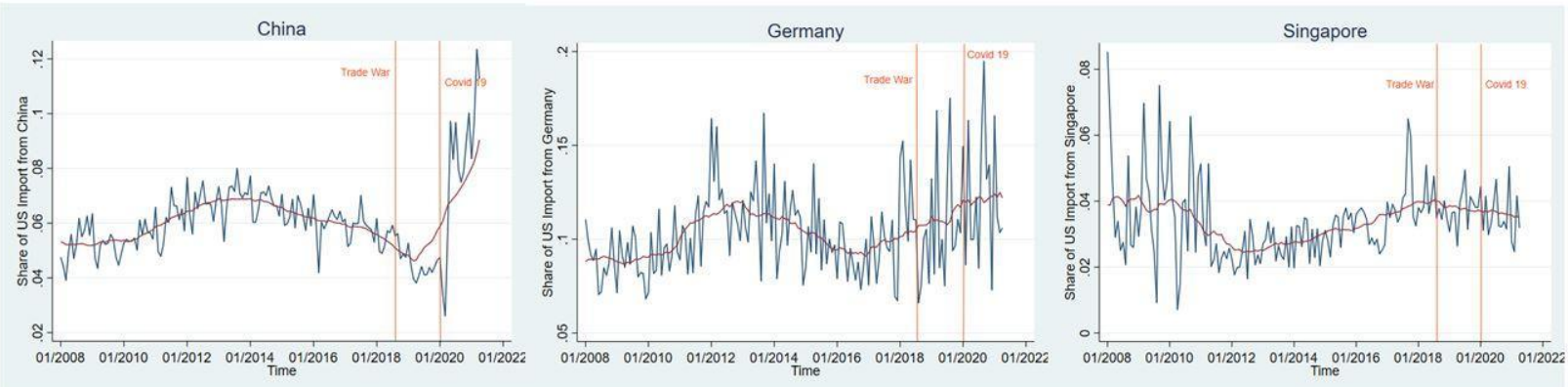

Notes and Sources: Data are from USA Trade Online. Blue line indicates monthly fluctuations. Red line indicates the 12-month moving averages.

Although the U.S.'s modest import of Chinese diagnostic kits remained stable during the Trade War, whereas its intake of made-in-China medical devices slumped, both of these pandemic-relevant categories witnessed dramatic export growths once COVID-19 hit North America. Going into the Trade War, Germany and Singapore maintained and increased exports of medical kits to the U.S., both in response to Sino-US tensions and as a result of the expanding healthcare industry in America. ${ }^{12}$ The story takes a different turn during the global pandemic, when German exports fell flat, Singapore's share slumped, and Chinese supply returned (Figure 4D-4E). China's export of medical apparatus to the U.S., which suffered a heavier blow in the Trade War, rose all the more dramatically during the pandemic.

Figure 4D: Share of US Diagnostics Import

01/2008-04/2021
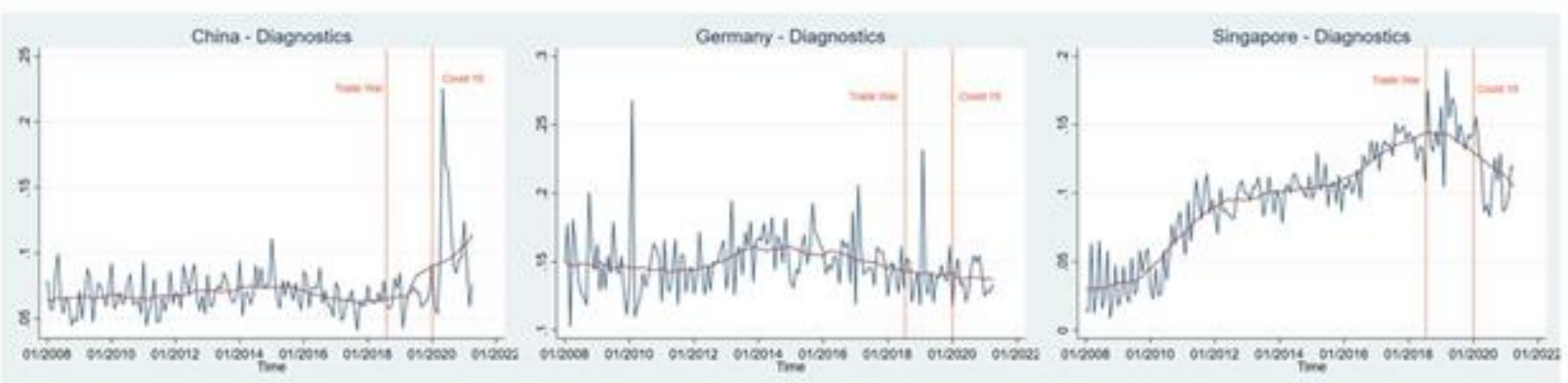

Notes and Sources: Data are from USA Trade Online. Blue line indicates monthly fluctuations. Red line indicates the 12-month moving averages.

\footnotetext{
${ }^{12}$ It is telling that even as the U.S. increased its monthly intake of medical apparatus from $\$ 522$ to $\$ 606$ million as a result of expanding domestic demand, China's share still dropped from $17 \%$ to $10 \%$, by $\$ 29$ million.
} 


\section{Figure 4E: Share of US Apparatus Import}

01/2008-04/2021
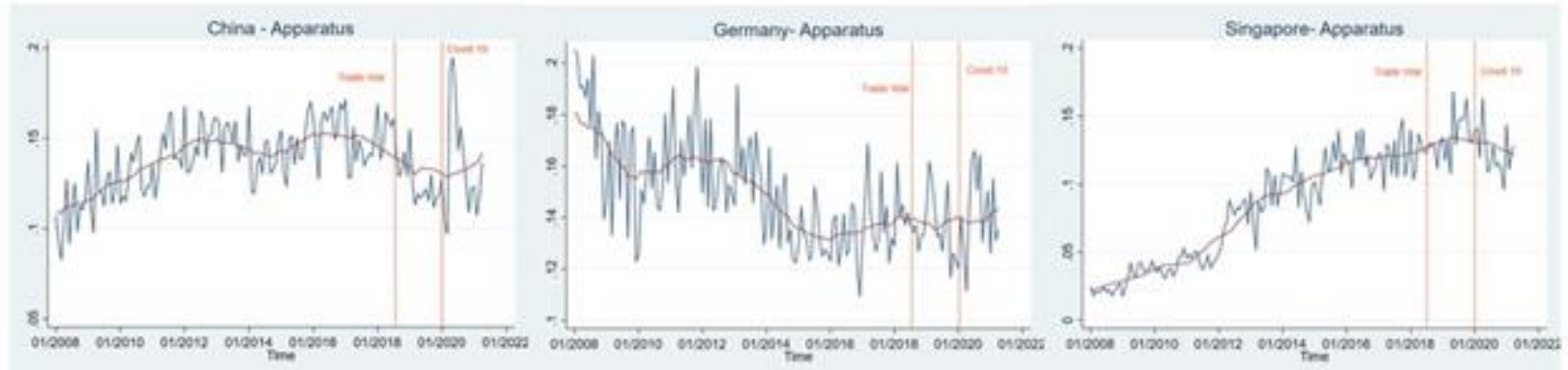

Notes and Sources: Data are from USA Trade Online. Blue line indicates monthly fluctuations, Red line indicates the 12 -month moving averages.

Figure 4F: Share of US Import from China

PPE, Hygiene, Syringe and Needles, Thermometers

01/2008-04/2021
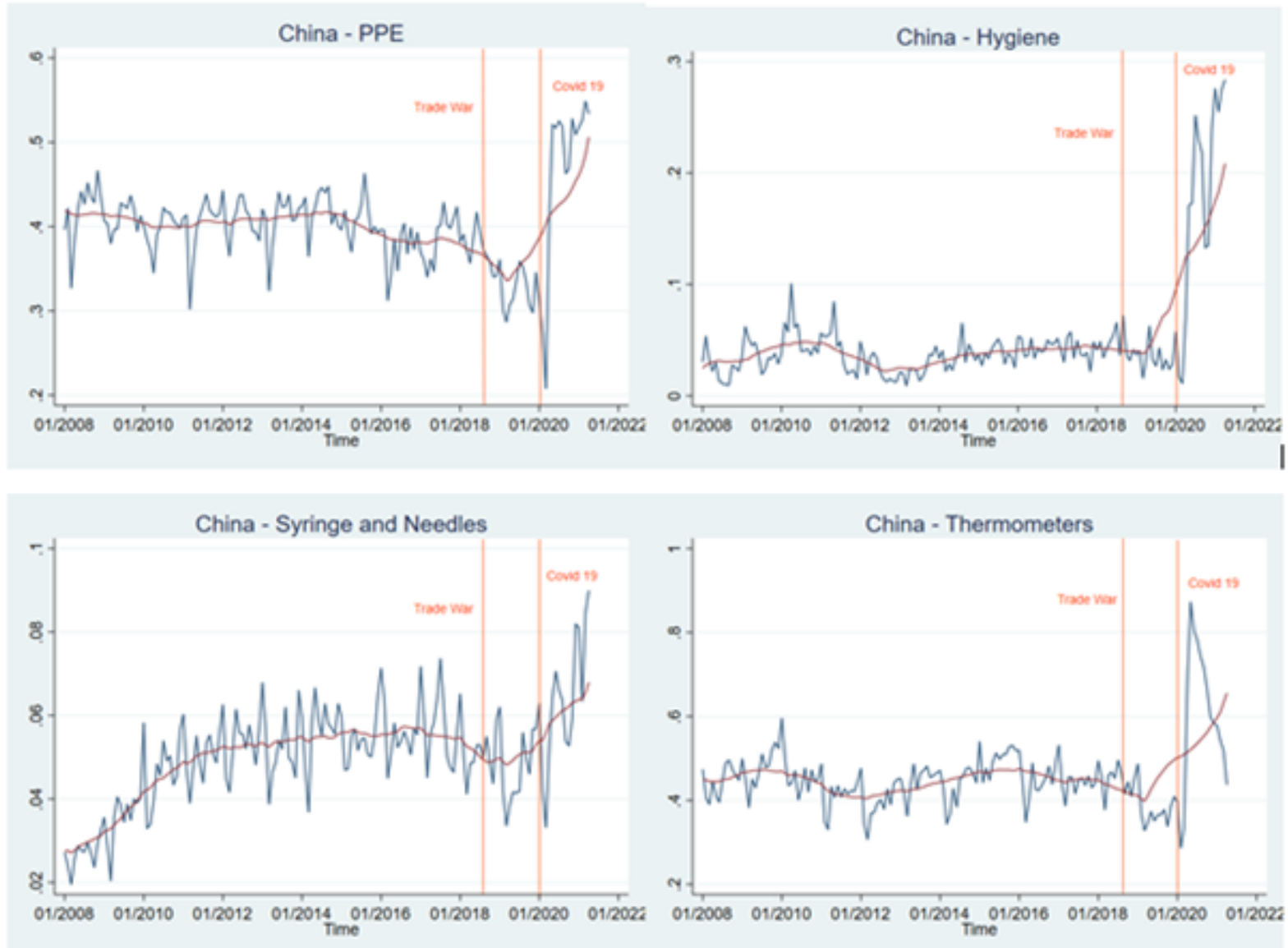

Notes and Sources: Data are from USA Trade Online. Blue line indicates monthly fluctuations. Red line indicates the 12-month moving averages. 
As a result of the Trade War, China's exports of mass-manufactured medical goods, especially PPE and thermometers, fell between 2018 and 2020. ${ }^{13}$ The trend persisted till the first three months of 2020, when Chinese producers poured resources into Hubei. Soon, however, a dramatic rebound in Chinese export ensued, when the U.S. scrambled and struggled to obtain medical products from China to fight its own war on COVID-19 (Figure 4F). This reversal wiped out America's short-lived detachment from made-inChina medical supplies.

Figure 4G: Share of US Import from China|

Medicament, Consumables and Vitamin 01/2008-04/2021
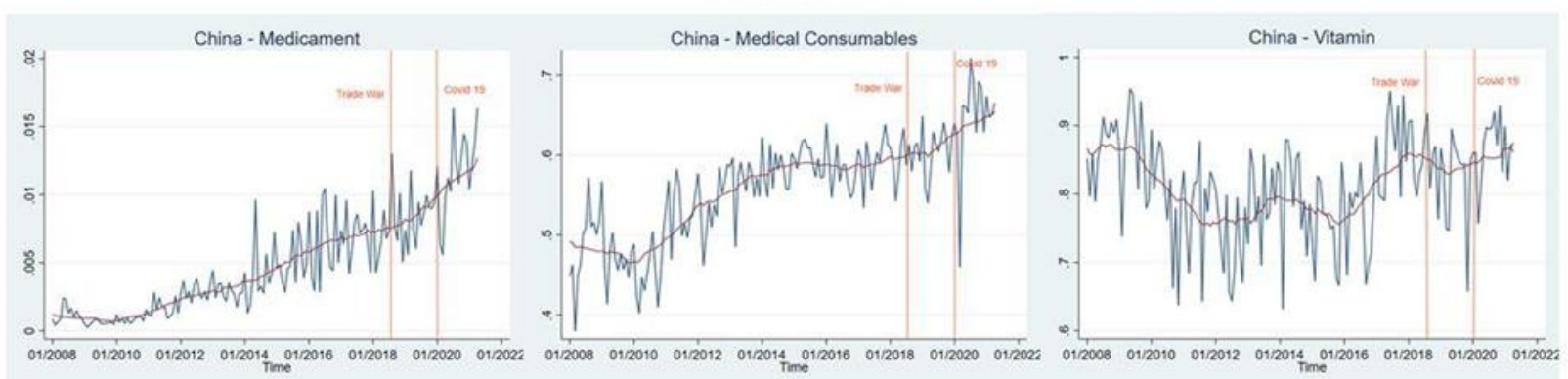

Notes and Sources: Data are from USA Trade Online. Blue line indicates monthly fluctuations. Red line indicates the 12-month moving averages.

The Trade War has left a varied impact on the global medical market, 2017-2021. Recently, economists have found, in the healthcare industry, cumulative abnormal returns of stock prices in the aftermath of escalations in Sino-U.S. trade tensions (Selmi et al, 2020). In the microscope, individual Chinese companies suffered the blow and felt the impact. According to an April 2020 interim financial statement issued by Mindray, the 34-billion U.S. tariffs slapped on Chinese goods negatively affected trade in patientmonitoring devices, CT-scanners, and anaesthetic machines from July 2018 to January 2020. Two months later, the U.S. started to stockpile medical kits and devices. Since then, China's share of US medical import has jumped from a dismal $2 \%$ to over a fifth of the total purchase worldwide.

Chronology and geography are two key factors in the resurgence of US reliance on Chinese medical supplies. Although not on par with the U.S. in bio-technology, China had accumulated a stockpile of protective equipment and respiratory devices by March 2020, an extra capacity subsequently channelled abroad as surplus export. No doubt, with the exception of

\footnotetext{
${ }^{13}$ Between January 2018 and March 2020, for instance, a gap in the monthly import of Chinese PPE from $38 \%$ to $21 \%$ entails a $\$ 90$ million difference in trade volume. Likewise, as America's monthly thermometer import remained nearly constant (around \$50-51 million), Chinese share dropped from $49 \%$ to $34 \%$.
} 
medicaments, consumables, and vitamins (Figure 4G), Chinese medical products have given way to Irish, German, and Southeast Asian substitutes during the Trade War. Furthermore, H1N1 data show that the U.S. has been able to leverage extra import from Ireland to combat the influenza pandemic. However, China's surplus proved critical in the COVID-19 pandemic in 2020, as nations around the world diverted their resources to domestic use. In this situation, the U.S. administration quietly issued a temporary reduction of import tariffs on Chinese-made medical products on 10 and 12 March 2020 (Office of the United States Trade Representative, 2020). Of course, Chinasceptical voices in Washington D.C. vow to reverse this reliance and to rebalance its medical trade as soon as the emergency ends. Whether, when, and how future administrations carry out the Congressional Research Service's vision for reduced medical reliance on China remains to be seen.

Figure 4H: US Import from the World 01/2008-04/2021

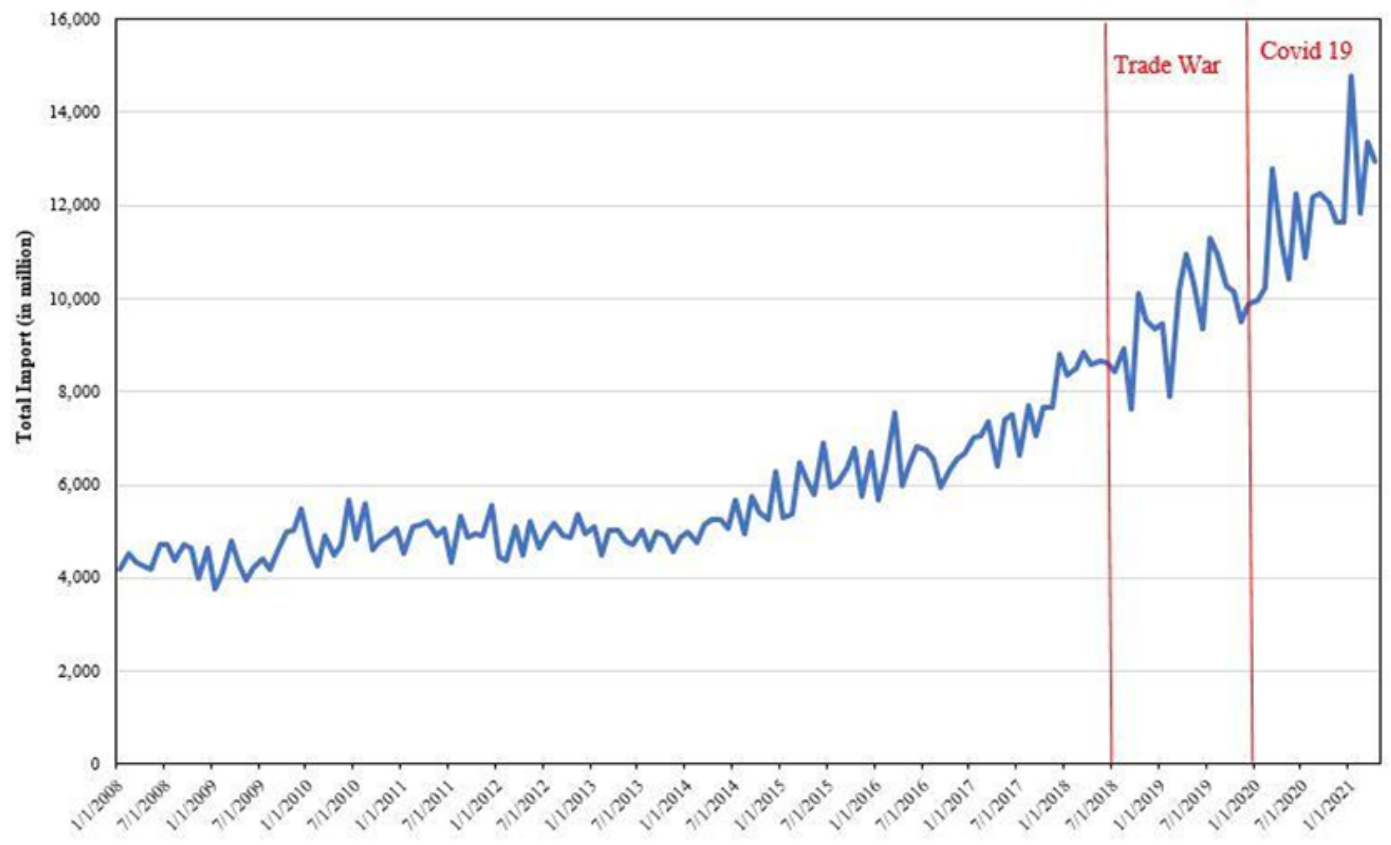

Notes and Sources: Data are from USA Trade Online.

For the time being, however, it is clear that the Trade War has restricted US access to medical resources on the eve of the COVID-19 pandemic. The public health crisis has, in turn, increased US reliance on Chinese medical supplies. An analysis of trade data endorses the statement that "an alarming unintended consequence of President Donald Trump's misguided trade war with China has suddenly threatened to cripple the US fight against the COVID-19 pandemic" albeit with important reservations (Bown, 2020). After 
all, trade disputes have reshuffled US reliance, but not reduced total import. Quite the contrary, US medical import grew over time (Figure 4H). It is right, however, that the Trade War blocked key pathways of obtaining vital medical products from China, until the White House quietly moved to relax tariffs to streamline medical trade.

\subsection{Vaccination in International Politics}

Along with frictions in transferring medical resources across markets and jurisdictions, the international politics of vaccination conspires to prolong the global public health crisis. The geo-politicisation of inoculation takes many forms, from partial interpretations of contextualised trial data, promotions or rejections of vaccines based on diplomatic priorities, to shifting allegations of supply-chain threats from foreign adversaries. Indeed, as vaccination programs unravelled in North America, Europe, and the United Kingdom, the problem has not been the ethics and economics of vaccination costs (Gilley and Dube, 2020), but the global justice of vaccine supplies. How should major powers, in quest of both domestic security and global clout, allocate their vaccines for use at home versus abroad?

Russia and China have famously prioritised exporting a portion of their vaccines to the developing world early on in their vaccination calendar. It is no secret that, on the other end of the trade-off scale, the U.S. has unabashedly prioritised self-inoculation over any donation or export, even to its handful of closest allies. The U.K. and India first sought a presence in Africa, before turning to redress shortages at home. This polarisation of vaccination strategies resulted in curious episodes. At one point, Serbia and the United Arab Emirates pulled ahead of the E.U. in vaccination rates, thanks to Russian and Chinese doses. With their jabs of Sputnik V, Sinopharm, or Sinovac, nations from Argentina and Chile to Indonesia and Malaysia rose quickly in the global vaccination ranking. Despite varying receptions from ridicule to gratitude, China and Russia have integrated vaccine aid into their broad pledges to engage with world development. After all, Africa, the Middle East, South Asia, and parts of Latin America, which still remain the least-vaccinated regions around the world, could not have afforded to wait for OxfordAstraZeneca, Pfizer-BioNTech, and Moderna to trickle down from wealthier and healthier nations.

If a globally equitable distribution of all available vaccines through a cosmopolitan government is beyond reach for the international community, is there still a case for nation-states to keep a balance in the trade-off between domestic delivery and international aid? And if governments spurn the medical council of international inoculation, would the argument of "national interest' cut? A game-theoretical analysis of vaccine strategies reveals that, when countries adopt independent strategies of promoting health at home and 
raising its profile abroad, equilibrium-solutions are not impossible (Figure 5). First, let there be two vaccine-producing players, China and a western government: medium-sized, wealthy, and research-intensive, such as the U.K. Let us assume, then, two points of advantage China holds over its western counterpart: (1) production of 12,000 doses for each 10,000 by its rival; (2) a smaller transaction cost (in the form of a percentage discount in the numerical proxy) for its marginal utility from increasing foreign aid, given that its population is (2a) further removed from largescale infections (2b) more habituated to sharing the re-distributive burdens of their government's committed fiscal transfers to developing nations in exchange for diplomatic support. Now, if a state distributes all doses within its borders, the utility function is set to equal one standard unit. Otherwise, a discount factor is introduced to the utility function of its vaccine diplomacy, which yields variably lower or slower returns than vaccination programs for the domestic audience. The utility equation is set as the following:

$$
W_{i}=\delta_{i}\left[\frac{S_{i} p_{i}}{\sum_{i=1}^{n} S_{i} p_{i}}\right]+\frac{S_{i}\left(1-p_{i}\right)}{S_{i}}
$$

where for each country $i, W_{i}$ indicates welfare or utility gained from public support: $S_{i}$ indicates the total amount of vaccines at hand; $p_{i}$ is the proportion of vaccines to be transferred as aid to developing countries; $\delta_{i}$ denotes the relative importance of international vs domestic audience in gaining public support. Below are the utility functions of the two countries in this scenario.

$$
\begin{aligned}
& W_{1}=0.8\left[\frac{S_{1} p_{1}}{S_{1} p_{1}+S_{2} p_{2}}\right]+\frac{S_{1}\left(1-p_{1}\right)}{S_{1}} \\
& W_{2}=0.9\left[\frac{S_{2} p_{2}}{S_{1} p_{1}+S_{2} p_{2}}\right]+\frac{S_{2}\left(1-p_{2}\right)}{S_{2}}
\end{aligned}
$$

Note that (1) n may be increased to reflect the multiparty game in the international arena (2) The discount rate for each player should be calculated based on a set of parameters, such as polls that assess the sensitivity of the domestic audience to fiscal transfers abroad, the responsiveness of overseas recipients of these transfers, as well as the international community's reception of such a diplomatic gesture (3) $S_{n}$ is determined by the vaccine inventory available at a given time of the game (4) what is modelled here is a one-time simultaneous game, but it can be revised to a sequential or repeated game (5) the different arrangements in the graph showcase a party's optimising strategy, given its rival's specific move (6) a marginal discount of 
0.05 unit is deducted from the utility of a player who invests in no transfer abroad, a feature designed to reflect the reality of relative reputation-damage as a result of the rival's total domination in international reputation and legitimation. Still, a commitment to vaccine-transfers, however small, eliminates this built-in punishment. (7) the game may suffer from imperfect information, where it is possible for a player to backward-induce its rival's actions. For example, India is able to reverse-engineer China's previous actions in the Middle East from an eventual outcome. In the rarer case of an incomplete game, where a player has access to its rival's actions but not its type, it is possible to use the Bayesian method to infer its type. For example, India is able to use the Bayesian method to update its own belief of Iran's real type, regardless of the regime's self-presentation. These procedures can be generalised to games of multiple players.

Figure 5: Simulated Payoffs in the Vaccine Game ${ }^{1}$

\begin{tabular}{|c|c|c|c|c|c|c|c|c|c|}
\hline & \multicolumn{9}{|c|}{ Share of Chinese Vaccine Export ${ }^{2}$} \\
\hline & $\mathbf{0}$ & 0.1 & 0.2 & 0.3 & 0.4 & 0.5 & 0.6 & 0.7 & 0.8 \\
\hline $\mathbf{0}$ & $0.95,0.95$ & $0.95,1.80$ & $0.90,1.70$ & $0.85,1.60$ & $0.80,1.50$ & $0.75,1.40$ & $0.70,1.30$ & $0.65,1.20$ & $0.60,1.10$ \\
\hline 0.1 & $1.70,0.95$ & $1.26,1.39$ & $1.14,1.44$ & $1.07,1.40$ & $1.04,1.34$ & $1.01,1.27$ & $1.00,1.19$ & $0.99,1.10$ & $0.98,1.02$ \\
\hline 0.2 & $1.60,0.90$ & $1.30,1.24$ & $1.16,1.29$ & $1.09,1.28$ & $1.04,1.24$ & $1.00,1.18$ & $0.97,1.10$ & $0.95,1.03$ & $0.94,0.94$ \\
\hline 0.3 & $1.50,0.85$ & $1.27,1.16$ & $1.14,1.20$ & $1.06,1.19$ & $1.01,1.15$ & $0.97,1.10$ & $0.94,1.04$ & $0.91,0.96$ & $0.89,0.89$ \\
\hline 0.4 & $1.40,0.80$ & $1.22,1.11$ & $1.10,1.14$ & $1.02,1.13$ & $0.96,1.09$ & $0.92,1.04$ & $0.89,0.98$ & $0.86,0.91$ & $0.84,0.84$ \\
\hline 0.5 & $1.30,0.75$ & $1.15,1.07$ & $1.04,1.09$ & $0.97,1.08$ & $0.91,1.04$ & $0.86,0.99$ & $0.83,0.93$ & $0.80,0.86$ & $0.77,0.79$ \\
\hline 0.6 & $1.20,0.70$ & $1.07,1.05$ & $0.97,1.06$ & $0.90,1.04$ & $0.84,1.00$ & $0.80,0.95$ & $0.76,0.89$ & $0.73,0.83$ & $0.71,0.75$ \\
\hline 0.7 & $1.10,0.65$ & $0.98,1.03$ & $0.90,1.03$ & $0.83,1.01$ & $0.77,0.97$ & $0.73,0.92$ & $0.69,0.86$ & $0.66,0.79$ & $0.64,0.72$ \\
\hline 0.8 & $1.00,0.60$ & $0.90,1.02$ & $0.82,1.01$ & $0.75,0.98$ & $0.70,0.94$ & $0.66,0.89$ & $0.62,0.83$ & $0.59,0.76$ & $0.56,0.69$ \\
\hline
\end{tabular}

Notes and Sources: Data are simulated.

' In a given cell, the first entry indicates the payoff for UK and the second entry indicates the payoff for China.

${ }^{2}$ These numbers represent the percentage of domestically-produced vaccines that are exported to developing countries.

The percentages range from 0 to $80 \%$, as we assume that no country would export over $80 \%$ of vaccines to other countries.

Intuitively, the basic trade-off mechanism in the game is the discount of translating foreign image into overall welfare. By complying with WHO's 
call for redistributing vaccines to poorer countries, Britain exchanges marginal utilities of domestic approval for marginal increases in its international profile, which may either feed back into domestic approval or add straight to its overall welfare. Since China enjoys a smaller discount rate, Britain's pursuit of an exclusively domestic vaccination program leaves itself worse off on the global stage. Thus, the game-theory analysis shows that by excluding the 'others,' an inward-looking vaccination strategy yields suboptimal outcomes not only in epidemiological practice but also in geopolitics. Thus, it is both in the interest of nation-states and for the end of global solidarity that they devote a portion of their vaccines to less resourceful communities around the world.

\subsection{The Global Politics of Medical Supplies: Europe, Middle East, South Asia, Africa and Latin America}

The pandemic wreaked havoc in East Asia, Europe and North America, ignited hotspots in Russia, India, Brazil, parts of Africa, and visited city-states and lone islands in the Asia-Pacific (Koley, 2021). The logistics of medical supplies, especially its transfer across territorial boundaries, is a global challenge for the international society as an organic whole.

Throughout the COVID-19 pandemic, the European Union has shown mixed signs of solidarity and disparity. Early on, the E.U. leveraged its transnational infrastructures to facilitate the free flow of critical information. On 28 January 2020, the Croatian presidency activated the E.U.'s Integrated Political Crisis Response Mechanism (IPCR)'s information sharing mode, which was raised to "full mode" on 2 March 2020. Likewise, the E.U. weaved international bioinformatic resources into a systematic network through the European Life Science Data Infrastructure (ELIXIR), across industries and academia (Blomberg and Lauer, 2020). However, such initiatives are restricted to the sharing of data and research, not goods and services. Quite the opposite, Europe has seen a resurgence of assertive nation-states as primary agents of pandemic relief. Early on in the COVID calendar, Berlin locked down key medical supplies that happened to fall inside German borders, at the discontent of Switzerland, Austria, and other neighbours without stockpiles for whom the uneven pre-pandemic distribution of warehouses within the European Economic Community (EEC) was a mere matter of logistical division. These first flexes, from border closures to export bans, revealed deep tensions between grand aspirations for supranational governance and deep concerns with national interests.

The economic disparity between EU member states, which provoked debates over fiscal transfers and debt-mutualisation instruments such as the rejected 'Coronabonds,' plagued the Common Market in the worst months of its public health crisis. Only extensive restrictions on debt-use convinced the creditor states to approve a package of funds from the European Stability 
Mechanism (ESM), the European Investment Bank (EIB), and the European Commission (EC). The lack of economic resources has further destabilised the medical infrastructures across Southern Europe, where healthcare professionals, caught in a state of moral distress between patient-centred care and public-oriented treatment, already groaned under budget cuts, especially in Italy and Spain (Faggioni et al, 2021). Resource scarcity forces less-funded offices to intensify the moral distinction between 'normal' vs 'emergency' times. The temporal concept of 'urgency' (necessitas), with its origins in classical and modern legal philosophies (Li, 2019), legitimates problematic prioritisations, such as those found in the guidelines on triage-based allocations of intensive care treatments by the Società Italiana di Anestesia, Analgesia, Rianimazione e Terapia Intensiva (SIAARTI) in Italy and the Sociedad Española de Medicina Intensiva, Crítica y Unidades Coronarias (SEMICYUC) in Spain. Therefore, the adequate provision of medical resources concerns not only the efficiency of economic organisation, but the very conditions of ethical life.

Nor is the E.U. designed to take public health policies into its own hands. In fact, Brussels explicitly defers to the nation-state's definition of its own healthcare policy, ${ }^{14}$ a deference to sovereign legislative politics that categorically differs from a central government's respect for regional autonomy in a healthcare system of devolution. For this reason, the European Centre for Disease Control and Prevention (ECDC), with only 300 employees, is a hub for sharing expertise, without real policy-making power vested in CDCs elsewhere. Nor is there any substantive power in the RescEU, the E.U. 's one-year-old organ for crisis response, which has proved itself a capable coordinator of interstate firefighting. As a result, the best performance that Brussels has registered is its creation of 'green corridors' that safeguards the flow of vital goods in the midst of nation-states scrambling to close down borders to reassure domestic electorates. Fiscally, the E.U. has unleashed its conventional economic tools-ESM and European Central Bank (ECB) measures, budgetary rules, the incomplete banking union, and the unemployment-reinsurance scheme "Support to Mitigate Unemployment Risks in an Emergency" (SURE) - to redress not only scarcity and poverty, but also inequity between the states during the epidemic. In these ways, the Coronavirus has reignited debates over interstate economic justice in the European sovereign debt crisis, 2009-2012. Whether Brussel's role is to be

\footnotetext{
${ }^{14}$ European Union Law, Document 12008E168: Consolidated version of the Treaty on the Functioning of the European Union - PART THREE: UNION POLICIES AND INTERNAL ACTIONS - TITLE XIV: PUBLIC HEALTH - Article 168 (ex Article 152 TEC), Official Journal 115, 09/05/2008 P. 0122 - 0124, No. 7: "Union action shall respect the responsibilities of the Member States for the definition of their health policy and for the organisation and delivery of health services and medical care."
} 
further reduced or expanded will shape the E.U. as a project in the postpandemic international society.

Not only the E.U. in particular, but international organisations in general, have ceded grounds to nation-states reasserting their agencies in the wake of the epidemic emergency. At a time when refugees are short of soaps, no more than 8 WTO members traded soaps duty-free. On the contrary, 78 WTO members slapped tariffs on soaps at $15 \%$ or more. Worldwide, from Bundeskanzleramt's interception of Swiss supplies, to the Élysée's prevention of mask deliveries to the British National Health Service (NHS), and to Taipei's ban of mask export to mainland China, isolationist COVID-19 task forces have, at least for a short while, garnered outstanding praises for their civic accountability. Such a "Sicken thy Neighbour" strategy, however, not only jeopardises the efficacy of antiviral campaigns, but also aggravates global disparities. For example, given the humble capacity of ventilatormanufacturing in Africa and Latin America, Middle East, and Central Asia, the suspension of ventilator-exports would virtually deprive the people in these countries, often inhabiting crowded urban spaces or roadless rural areas, from receiving life-saving healthcare services (Musyoka et al, 2018; Evenett, 2020). Furthermore, it must be noted that macro-data in pan-regions do not fully reflect the medical conditions on the ground, for these areas suffer internal disparity, as well. Within the Arab world, for example, considerable disparity exists between the struggling Comoros, Djibouti, Mauritania, Somalia, and Sudan, and the more resourceful Algeria, Egypt, Jordan, Morocco and Tunisia (Hadrya et al, 2021). And within South Asia, the pandemic experiences of urban vs rural India are drastically different (Jha et al, 2021). Therefore, the point is not only to transfer resources across macroregions, but also to deliver them to micro-spaces.

The global pandemic has exacerbated not only pre-existing socioeconomic disparities between diverse communities, but also simmering tensions in local political lives. In Brazil, notwithstanding successful local redistributive experiments such as the "emergency basic income" (EBI) plan in Maricá (De Wispelaere and Morales, 2021), a chorus of conflicting public policies, geopolitical interests, and a general shortage of medical resources has inflicted unnecessarily high casualties. Some scholars point to "ideological misconceptions" as the cause of pandemic failures in Latin America (Litewka and Heitman, 2020). More generally, in Brazil, local and national political rivalries ramified through all areas of public policy-lockdown, (re)distributions, masking, and treatment, as well as the import of medical supplies, such as medicine, devices, and vaccines, from 'adversarial' nationstates abroad to hotly contended constituencies at home. The hope that in Latin America, "its ruling classes can rise to the occasion and find common ground to rebuild what is left" after the COVID-19 pandemic is a dire, 
untransformative, and unrealistic hope (Litewka and Heitman, 2020). Instead, the world's survivors of not only the Coronavirus but also inadequate national and international public policies are poised to build a global vision for public health, to normalise bioethics in the sphere of law and right (Freeman, 2008), and to extend these efforts beyond the medical world.

Apart from the distributive justice of healthcare resources, the COVID19 pandemic has brought out the contradictions within pre-existing bioethical principles, from the right to privacy (Sperling, 2008) to the legitimacy of quasi-wartime humanitarian interventions (Landesman, 2008); from the inconsistency, iatrogenesis, and over-medicalisation of society (Illich, 1976), to the relational autonomy, reciprocity, and solidarity of healthcare professionals in states of isolation, social distancing, and moral distress (Herring. 2008; Jeffrey, 2020). Indeed, the epidemic reveals the antagonism of partial truths, and sunders the meanings of ideas. Does trust, for example, entail 'social contagion' that is correlated with higher infection rates (Elgar et al, 2020), or 'social cohesion' that is associated with higher compliance with public health protocols (Kye and Hwang, 2020)? Is ethics the master or victim of healthcare policies that sacrifice human sociability for lower infections rates? And is efficiency in the medical market the friend or enemy of global healthcare justice? Of all these questions, this paper focuses on the inequitable and inadequate transfer of medical supplies, from the auction of ventilators to the geopolitics of vaccination. Still, it must be pointed out that pandemic equity concerns not only equipment, but healthcare as a social experience (Balsari et al, 2020). Underlying and outliving the COVID-19 pandemic is a broader socio-environmental crisis that forces humanity to reconsider its relationship with each other and nature. Health and environment, as public goods, recognise no territoriality. Unfortunately, where they are not transacted as privileges, they are considered to be public goods only within the scope of bounded political spaces. As a result, cross-jurisdictional effects, intercontinental damages, and longer-term costs do not factor into the calculus of public policies. Thus, the current crisis is a fitting time to rethink the failures of both markets and governments, and to launch more sustainable forms of production, exchange, and social life.

\section{Conclusion}

Through mixed methods of case studies, empirical analysis, modelling, and game theory, this paper identifies supply-chain disintegration, inequity in medical distribution, and political barriers to resource allocation as the focal points of the global challenge of the COVID-19 Pandemic.

An analysis of the medical market shows that public health depends significantly on the medical suppliers' ability to realign innovations with social welfare in a time of epidemic emergency. Based on empirical evidence, 
the authors of the paper recommend digital integration of the medical supply chain through global distributing platforms.

Next, the paper seeks to overcome the perceived 'moral deficit' of current distributing algorithms, especially in the contexts of exchanging vital medical supplies. The ethical allocation of life-saving ventilators during a public health crisis tests the "practical ramifications" of an arete-eudaimonic approach to bioethics (Sideri, 2008). Whilst the personal 'virtue' of physicians and their contribution to communal 'flourishing' have taken the centre stage of bioethical thought since the Hippocratic oath, Moses Maimonides's Kitāb al-fușūl fì al-țibb, and al-Razi's Man La Yahdurah al-tabib, this approach sheds little light on global distributive justice under the condition of medical scarcity. The just distribution of vital medical supplies has acquired increasing salience as a social, political, and moral issue after the industrial, commercial, and digital transformations in the past two centuries. Indeed, the ethical allocation of scarce healthcare resources has been identified as a key question of moral theory and medical practice, from the polio epidemics in the early $20^{\text {th }}$ century - a key context for the first applications of 'ventilators' (Geddes, 2007) - to the rise of modern bioethics in the wake of new biotechnologies since the 1970s (Freeman, 2008), and to the 2006 avian influenza A (H5N1) pandemic (Gostin, 2006). This paper takes this thorny issue creatively, but also pragmatically, by postulating a price-based but need-conscious distribution to replace existing models that are solely based on oftentimes distorted prices, compromised by information asymmetry, and subject to market manipulations.

Finally, an empirical study of trade data shows that the Trade War in 2017-2019, which caused a plunge in US import of Chinese medical supplies before a dramatic rebound during the COVID-19, served neither US preparedness for the pandemic nor its plan to reduce reliance on Chinese medical products: PPE and apparatus, hygiene and consumables, syringe and needles. Just as the U.S. struggles to redress not only interstate but also intercounty impacts of the COVID-19 (Chin et al, 2020; Kiang et al, 2020), the E.U. is grappling with the twofold structural problems of interstate disparity and local inequalities. Since the pandemic intensifies the "inescapable network of mutuality" - in the words of Martin Luther King Jr. (King, 1963) — of the entire human community, it is not only possible, but also desirable and necessary to launch peacetime preparations for justice in future pandemics, such as building infrastructures for vulnerable populations (Francis et al, 2008). After all, a pandemic interweaves culture, trade, and human relations (Pera and van Tonder, 2005) into a large ethico-economic canvass. Within the medical market, the way forward is to identify both micro and macro mechanisms to ensure not only efficient but also ethical distribution 
of medical supplies, in order to prepare for future crises of grave magnitudes and global scales.

Conflict of Interest: The authors declare no conflict of interest.

Acknowledgement: The authors would like to thank Brian Seo of Harvard College for his research assistance, Michael Weishan at the Franklin Delano Roosevelt Foundation for generous support, the two anonymous reviewers appointed by the European Scientific Journal for their comments and critiques, as well as Anthony Sanglay Jr. and Suuchi Ramesh for their insights.

\section{References:}

1. Ahlbach, C., King, T., Dzeng, E. (2021). The COVID-19 Pandemic and Ethical Challenges Posed by Neoliberal Healthcare. Journal of General Internal Medicine 36(1): 205-206.

2. Applbaum, A.I. (2017). The Idea of Legitimate Authority in the Practice of Medicine. AMA Journal of Ethics 19(2): 207-213.

3. Archibugi, D.; Filippetti, A.; Frenz, M. (2013). The Impact of the Economic Crisis on Innovation: Evidence from Europe. Technological Forecasting and Social Change 80(7): 1247-1260.

4. Balsari, S., Sange, M., Udwadia, Z. (2020). COVID-19 Care in India: The Course to Self-Reliance. The Lancet Global Health 8(11): p.e1359-e1360.

5. BD: Becton, Dickinson and Company (2020). BD Announces $\$ 24$ Million U.S. Government Investment to Support Scale Up of U.S. Manufacturing of COVID-19 Diagnosic Tests: Capital investments will enable U.S. manufacturing of 8 million BD Veritor ${ }^{\mathrm{TM}}$ brand SARS-CoV-2 tests per month, PRNewswire (https://www.prnewswire.com/news-releases/bd-announces-24million-us-government-investment-to-support-scale-up-of-usmanufacturing-of-covid-19-diagnosic-tests-301103539.html).

6. Belhouideg, S. (2020). Impact of 3D Printed Medical Equipment on the Management of the Covid19 Pandemic. The International Journal of Health Planning and Management 35(5): 1014-1022.

7. Blomberg, N., Lauer, K.B. (2020). Connecting Data, Tools and People across Europe: ELIXIR's Response to the COVID-19 Pandemic. European Journal of Human Genetics 28(6): 719-723.

8. Blumenthal-Barby, J., Boyd, K., Earp, B.D., Frith, L., McDougall, R.J., McMillan, J., Wall, J. (2020). Pandemic Medical Ethics. Journal of Medical Ethics 46(6): 353-354. 
9. Bown, C.P. (2020). Trump's Trade Policy is Hampering the US Fight against COVID-19. Peterson Institute for International Economics (Trade and Policy Investment Watch:

https://www.piie.com/blogs/trade-and-investment-policywatch/trumps-trade-policy-hampering-us-fight-against-covid-19).

10. Burki, T. (2020). The Indirect Impact of COVID-19 on Women. Lancet: Infectious Diseases 20(8): 904-905.

11. Butler, J. (1997). The Psychic Life of Power: Theories in Subjection. Stanford: Stanford University Press.

12. Chin, T., Kahn, R., Li, R., Chen, J.T., Krieger, N., Buckee, C.O., Balsari, S., Kiang, M.V. (2020). US-county Level Variation in Intersecting Individual, Household and Community Characteristics Relevant to COVID-19 and Planning an Equitable Response: a CrossSectional Analysis. BMJ Open 10(9): p.e039886-e039886.

13. Cohen, L. (2020). The Culling: Pandemic, Gerocide, Generational Affect. Medical Anthropology Quarterly 34(4): 542-560.

14. Cousins, S. (2020) COVID-19 Has "Devastating" Effect on Women and Girls. The Lancet 396(10247): 301-302.

15. Ćurković, M., Košec, A., Ćurković, D. (2020). Medical Professionalism in Times of COVID-19 Pandemic: is Economic Logic Trumping Medical Ethics? Internal and Emergency Medicine 15(8): 1585-1586.

16. Davis, J.P.; Eisenhardt, K.M.; Bingham, C.B. (2009). Optimal Structure, Market Dynamism, and the Strategy of Simple Rules. Administrative Science Quarterly 54(3): 413-452.

17. del Ángel, M., Fohlin, C., Weidenmier, M.D. (2021). Do Global Pandemics Matter for Stock Prices? Lessons from the 1918 Spanish Flu. NBER (working paper).

18. Du Pont, D., Baren, J. (2020). Ambulance Charters during the COVID19 Pandemic and Equitable Access to Scarce Resources. American Journal of Bioethics 20(10): 7-9.

19. Easley, D., Kleinberg, J. (2010). Networks, Crowds, and Markets: Reasoning about a Highly Connected World Book. Cambridge, Cambridge University Press.

20. Elgar, F.J., Stefaniak, A., Wohl, M.J.A. (2020). The Trouble with Trust: Time-series Analysis of Social Capital, Income Inequality, and COVID-19 Deaths in 84 Countries. Social Science \& Medicine 263: $113365-113365$.

21. Evenett, S.J. (2020). "Sicken thy Neighbour: The Initial Trade Policy Response to Covid-19" The World Economy, 43(4): 828-839.

22. Evenett, S., Fiorini, M., Fritz, J., Hoekman, B., Lukaszuk, P., Rocha, N., Ruta, M., Santi, F., Shingal, A. (2021). Trade Policy Responses to 
the COVID-19 Pandemic Crisis: Evidence from a New Data Set. World Economy: 1-23.

23. Faggioni, M.P., González-Melado, F.J., Di Pietro, M.L. (2021). National Health System Cuts and Triage Decisions during the COVID19 Pandemic in Italy and Spain: Ethical Implications. Journal of Medical Ethics 47(5): 300-307.

24. FIOR Markets (2020). Global Hand Sanitizer Market Is Expected to Reach USD 2.14 Billion by 2027. Intrado GlobeNewswire (https://www.globenewswire.com/newsrelease/2020/03/26/2007160/0/en/Global-Hand-Sanitizer-Market-IsExpected-to-Reach-USD-2-14-Billion-by-2027-Fior-Markets.html).

25. Francis, L.P., Battin, M.P., Jacobson, J.A., Smith, C.B. (2008). Pandemic Planning and Distributive Justice in Health Care, in Freeman, M. Law and Bioethics: Current Legal Issues 11. Oxford: Oxford University Press.

26. Freeman, M. (2008). Law and Bioethics: Constructing the InterDiscipline, in Freeman, M. Law and Bioethics: Current Legal Issues 11. Oxford: Oxford University Press: 1-11.

27. Gardiner, R.A., Fulfer, K. (2021). Virus Interruptus: An Arendtian Exploration of Political World-building in Pandemic Times. Gender, Work, and Organization 28(S1): 151-162.

28. Geddes, L.A. (2007). The History of Artificial Respiration. IEEE Engineering in Medicine and Biology Magazine 26(6): 38-41.

29. Getinge. (December 10, 2020). Report on Getinge COVID-19 Commercial Paper

(https://www.getinge.com/dam/corporate/documents/investors/geting e-prospect/english/report_on_getinge_covid-19_commerical_paperen-non_us.pdf).

30. Gilley, R.P., Dube, P.H. (2020). "Free Vaccinations for All Is, Morally and Economically, the Right Way to Prepare for Pandemic and Seasonal Respiratory Infections" American Journal of Public Health 110(8): 1143-1144.

31. Gostin, L.O. (2006). Medical Countermeasures for Pandemic Influenza: Ethics and the Law. JAMA: The Journal of the American Medical Association 295(5): 554-556.

32. Hadrya, F., El Hattimy, F., Hami, H., Mokhtari, A., Soulaymani, A. (2021). Covid-19 Pandemic Situation in The Arab World till June 11, 2020: Spatial Panorama Obtained Following the Response Plan Implemented. European Scientific Journal, ESJ, 17(3), 176.

33. Hart, N. (2020). COVID-19: An Overview of Trade-Related Measures to Address Access to Medical Goods, Washington D.C.: Congressional Research Service, LSB10424. 
34. Herring, J. (2008). The Place of Carers, in Freeman, M. Law and Bioethics: Current Legal Issues 11. Oxford: Oxford University Press.

35. Hodge, J.G., Wetter, S., Carey, E., Pendergrass, E., Reeves, C.M., Reinke, H. (2020). Legal "Tug-of-Wars" During the COVID-19 Pandemic: Public Health v. Economic Prosperity. The Journal of Law, Medicine \& Ethics 48(3): 603-607.

36. Honneth, A. (2018). Anerkennung. Eine europäische Ideengeschichte. Berlin: Suhrkamp.

37. IBM Institute for Business Value (May 1 2020). IBM Study: COVID19 Is Significantly Altering U.S. Consumer Behavior and Plans PostCrisis Personal Mobility, Retail Shopping, and Event Attendance Are Among the Areas Most Impacted. PRNewswire (https://newsroom.ibm.com/2020-05-01-IBM-Study-COVID-19-IsSignificantly-Altering-U-S-Consumer-Behavior-and-Plans-PostCrisis).

38. Illich, I. (1976). Medical Nemesis: The Expropriation of Health. New York: Pantheon Books.

39. ISM: Institute for Supply Management (2020). COVID-19 Global Supply Chain Disruptions Continue. Cision $P R$ Newswire (https://www.prnewswire.com/news-releases/covid-19-global-supplychain-disruptions-continue-301040385.html).

40. Jamróz, W., Szafraniec, J., Kurek, M., Jachowicz, R. (2018). 3D Printing in Pharmaceutical and Medical Applications-Recent Achievements and Challenges. Pharmaceutical Research 35(9): 1-22.

41. Jeffrey, D.I. (2020). Relational Ethical Approaches to the COVID-19 Pandemic. Journal of Medical Ethics 46(8): 495-498.

42. Jha, S., Goyal, M.K., Gupta, B., Gupta, A.K. (2021). A Novel Analysis of COVID 19 Risk in India Incorporating Climatic and Socioeconomic Factors. Technological Forecasting \& Social Change 167: 12067.

43. Khanna, T. (2014). Contextual Intelligence. Harvard Business Review 92(9): 58-68.

44. Khanna, T., Palepu, K.G., Bullock, R. (2010). Winning in Emerging Markets: A Roadmap for Strategy and Execution. Cambridge, MA: Harvard Business Press.

45. Kiang, M., Irizarry, R.A., Buckee, C.O., Balsari, S. (2020). Every Body Counts: Measuring Mortality From the COVID-19. Pandemic Annals of Internal Medicine 173(12): 1004-1007.

46. King, M.L. (1963). A Letter from Birmingham Jail. Houston: Johnson Pub. Co.

47. Kye, B., Hwang, S.J. (2020). Social Trust in the Midst of Pandemic Crisis: Implications from COVID-19 of South Korea. Research in Social Stratification and Mobility 68: 100523-100523. 
48. Landesman, B.M. (2008). Humanitarian Intervention and Medical Epidemics, in Freeman, M. Law and Bioethics: Current Legal Issues 11. Oxford: Oxford University Press.

49. Levinthal, D., March, J.G. (1981). A Model of Adaptive Organizational Search. Journal of Economic Behavior \& Organization 2(4): 307-333.

50. Li, H. (2019). Time, Right and the Justice of War and Peace in Hugo Grotius's Political Thought. History of European Ideas 45(4): 536552.

51. Litewka, S.G., Heitman, E. (2020). Latin American Healthcare Systems in Times of Pandemic. Developing World Bioethics 20(2): 6973.

52. Lopez-Casasnovas, G., Pellise, L. (2016). Resource Allocation and Priority Setting in Health Care Systems, in Scheffler, R.M. World Scientific Handbook of Global Health Economics and Public Policy. New Jersey: World Scientific: 363-402.

53. McKinsey \& Company (2020). Consumer Sentiment and Behaviour Continue to Reflect the Uncertainty of the COVID-19 Crisis (https://www.mckinsey.com/business-functions/marketing-andsales/our-insights/a-global-view-of-how-consumer-behavior-ischanging-amid-covid-19).

54. Medtronic plc. (March 30, 2020). Medtronic Shares Ventilation Design Specifications to Accelerate Efforts to Increase Global Ventilator Production. Globe Newswire (https://newsroom.medtronic.com/news-releases/news-releasedetails/medtronic-shares-ventilation-design-specificationsaccelerate).

55. Müller, R. (1985). "Corporate Crisis Management" Long Range Planning, 18(5): 38-48.

56. Musyoka, P. K., Korir, J., Omolo, J., \& Nzai, C. C. (2018). An Empirical Analysis of the Effect of Poverty on Health Care Utilization in Kenya. European Scientific Journal, ESJ, 14(22), 101.

57. National Academies of Sciences, Engineering, and Medicine (NASEM): Health and Medicine Division; Board on Health Sciences Policy (2018). Impact of the Global Medical Supply Chain on SNS Operations and Communications: Proceedings of a Workshop. Washington D.C.: National Academies Press.

58. Office of the United States Trade Representative (2020). Notice of Product Exclusions: China's Acts, Policies, and Practices Related to Technology Transfer, Intellectual Property, and Innovation. Federal Register 85 (47): 13970-13973; 85 (52): 15244-15248. 
59. Paunov, C. (2012). The Global Crisis and Firms' Investments in Innovation" Research Policy 41(1): 24-35.

60. Pera, S.A.; van Tonder, S. (2005). Ethics in Health Care (2nd ed.). Lansdowne, South Africa: Juta.

61. Reich, M.R., Bery, P. (2005). Expanding Global Access to ARVs: The Challenges of Prices and Patents, in Mayer, K.H., Pizer, H.F. (2005) The AIDS Pandemic: Impact on Science and Society. Amsterdam; Boston: Elsevier Academic Press.

62. Relman, D.A., Choffnes, E.R., Mack, A. (2010). The Domestic and International Impacts of the 2009-H1N1 Influenza A pandemic: Global Challenges, Global Solutions: Workshop Summary. Washington D.C.: National Academies Press.

63. Rhodes, R., Battin, M.P., Silvers, A. et al. (2012). Medicine and Social Justice: Essays on the Distribution of Health Care. New York: Oxford University Press.

64. Rodríguez, M., Urbanos-Garrido, R. (2016). Inequalities and Inequities in Health and Health Care, in Scheffler, R.M. World Scientific Handbook of Global Health Economics and Public Policy. New Jersey: World Scientific: 489-557.

65. Sabatello, M., Burke, T. B., McDonald, K.E., Appelbaum, P.S. (2020) "Disability, Ethics, and Health Care in the COVID-19 Pandemic" American Journal of Public Health 110(10): 1523-1527.

66. Savulescu, J., Persson, I., Wilkinson, D. (2020). Utilitarianism and the Pandemic. Bioethics 34(6): 620-632.

67. Schumpeter, J.A. (1934). The Theory of Economic Development, (tr.) Opie, R. Harvard Economic Studies 46: 1600-0404.

68. Selmi, R., Errami, Y., Wohar, M.E. (2020). What Trump's China Tariffs Have Cost U.S. Companies? Journal of Economic Integration 35(2): 282-295.

69. Sideri, K., (2008). Health, Global Justice, and Virtue Bioethics, in Freeman, M. Law and Bioethics: Current Legal Issues Volume 11. Oxford: Oxford University Press.

70. Smith, R., Keogh-Brown, M., Hanefeld, J. (2016). Macroeconomics, Trade and Health, in Scheffler, R.M. World Scientific Handbook of Global Health Economics and Public Policy. New Jersey: World Scientific: $155-175$.

71. Sperling, D. (2008). Law and Bioethics: A Rights-Based Relationship and Its Troubling Implications, in Freeman, M. Law and Bioethics: Current Legal Issues 11. Oxford: Oxford University Press.

72. Stein, M. (2002). The Distribution of Life-Saving Medical Resources: Equality, Life Expectancy, and Choice Behind the Veil. Social Philosophy and Policy 19(2): 212-245. 
73. Sutter, K.M., Sutherland, M.D., Schwarzenberg, A.B. (2020). COVID19: China Medical Supply Chains and Broader Trade Issues. Washington, D.C.: Congressional Research Service, CRS report R46304.

74. Taubenberger, J.K., Reid, A.H., Lourens, R.M., Fanning, T.G., Jin, G., Wang, R. (2005). Characterization of the 1918 Influenza Virus Polymerase Genes. Nature 437: 889-89316208372.

75. Taylor, C. (1992). The Politics of Recognition, in Multiculturalism: Examining the Politics of Recognition, in Gutmann, A. (ed.), Princeton: Princeton University Press: 25-73.

76. Thompson, A.K., Smith, M.J., McDougall, C.W., Bensimon, C., Perez, D.F. (2015). With Human Health It's a Global Thing: Canadian Perspectives on Ethics in the Global Governance of an Influenza Pandemic. Journal of Bioethical Inquiry 12(1): 115-127.

77. Tolchin, B., Hull, S.C., Kraschel, K. (2021). Triage and Justice in an Unjust Pandemic: Ethical Allocation of Scarce Medical Resources in the Setting of Racial and Socioeconomic Disparities. Journal of Medical Ethics 47(3): 200-202.

78. Tumpey, T.M., Basler C.F., Aguilar P.V., Garcia-Sastre, A., Hui, Z., Solorzano, A., Swayne, D.E., Cox, N.J., Katz, J.M., Taubenberger, J.K., Palese, P. (2005). Characterization of the Reconstructed 1918 Spanish Influenza Pandemic Virus. Science 310: 77-8016210530.

79. Wenham, C., Smith, J., Morgan, R. (2020). COVID-19: The Gendered Impacts of the Outbreak. Lancet 395 (10227): 846-848.

80. De Wispelaere, J., Morales, L. (2021). Emergency Basic Income during the Pandemic. Cambridge Quarterly of Healthcare Ethics 30(2): 248-254. 